\title{
Bases sociales de la insurgencia en las regiones mineras y azucareras del sur de la capital novohispana $(1810-1812)^{*}$
}

\author{
Brígida von Mentz
}

\begin{abstract}
Siempre ha sido difícil para el historiador tener evidencias de la manera de vivir y de pensar de las clases subalternas en el pasado. En este estudio se pretende mostrar la riqueza de los testimonios de algunos reos (resumidos en dos cuadros) para documentar las circunstancias en las que participaron en la guerra civil de $1810-1812$ en la zona minera de Taxco-Sultepec y en los valles del actual estado de Morelos. A partir de la historia económica y social, se mencionan también las profundas tensiones sociales en esas regiones para explicar las bases sociales del movimiento insurgente.
\end{abstract}

PALABRAS CLAVE: lucha armada I8I0-I8I2, sectores trabajadores, latifundistas azucareros, oligarquía minera, violencia, sociedad estamental

Social Bases of the Insurgency in the Mining and Sugar South Regions of New Spain Capital (1810-1812)

It has been always difficult for historians to cull evidence about the ways of life and ideas of the subaltern classes. This study attempts to show the wealth of information from the testimonies of some inmates (summarized in two charts) in order to document the circumstances in which they were involved during the civil war of $1810-1812$ in the mining area of Taxco-Sultepec and the valleys of what is now the state of Morelos. Based on economic and social history, we learn of cases of deep social tensions that explain the social basis of insurgent movements in these regions.

KEYWORDS: armed struggle $18|0-18| 2$, workers sectors, sugar plantation owners, mining oligarchy, violence, hierarchical society

BRÍGIDA VON MENTZ : Centro de Investigaciones y Estudios Superiores en Antropología Social-Distrito Federal, México mentz@ciesas.edu.mx

Desacatos, núm. 34, septiembre-diciembre 2010, pp. 27-60

Recepción: 31 de agosto de 2009 / Aceptación: 7 de enero de 2010

* Agradezco sus comentarios críticos a versiones anteriores de este ensayo a los amigos de siempre Yolanda Montiel y David Navarrete, y a los dos dictaminadores anónimos. 
$\mathrm{L}$ a pregunta central que se plantea este estudio es: ¿por qué se adhirieron numerosos indígenas de pueblos pequeños y trabajadores rurales de las regiones de Cuernavaca y Taxco a la lucha iniciada en septiembre de 1810 en Dolores? A partir de algunas declaraciones de los reos y, sobre todo, a partir de la historiografía regional, se sostiene la hipótesis de que su participación en las primeras contiendas responde a una animadversión que se gestó desde fines del siglo XVIII contra quienes detentaban el poder político y económico en estas zonas ricas en plata, azúcar, aguardiente y ganado. Aunque las evidencias proporcionadas por los combatientes aprehendidos no pueden ser contundentes - ¿quién declararía, ante el peligro de ser fusilado o exiliado a La Habana, que fue insurgente por convencimiento?-, los contrastes sociales en estas regiones cuyas empresas destacan por su riqueza y las tensiones al interior de las élites regionales permiten, a nuestro modo de ver, lanzar la hipótesis de una participación popular entusiasta en los primeros días y meses de guerra.

Se presentarán primero las experiencias de distintos pec y posteriormente las de otros en los valles azucareros de Cuernavaca en los primeros años de insurrección. Con los testimonios de algunos participantes se combina la mención de la estructura productiva de esas zonas, cuyo desarrollo ya se ha estudiado. En contraste con las numerosas obras históricas sobre la Guerra de Independencia ${ }^{1}$, aquí el enfoque es económico y social, así como regional y puntual. Sin embargo, al final se aventuran interpretaciones más generales sobre cambio y continuidad en nuestra historia, es decir, sobre la dialéctica entre el cambio revolucionario y el parteaguas que fue esa guerra — tesis que se sostiene en este trabajo_ y la continuidad

\footnotetext{
${ }^{1}$ Entre las obras más recientes es importante el estudio de Eric Van Young (2006), que abarca toda la década de guerra y todo el territorio de la Nueva España. Hace énfasis en aspectos culturales, religiosos y psicológicos. Según el propio autor, se trata de una "etnografía densamente descriptiva”. Véase también Hernández Jaimes, 2002; Ortiz Escamilla, 1997. Para una interpretación de los orígenes de la insurrección a partir de las especificidades regionales es excelente el análisis de Hamnett, 1990. Obras clásicas son, además, Alamán, 1972; Bustamante, 1988; Chávez Orozco, 1976; Guedea, 1995a; Lemoine, 1990; De la Torre Villar, 1966.
}

de la desigualdad social y de los conflictos socioeconómicos arraigados en ciertas zonas, durante largos periodos.

Partimos de análisis realizados previamente sobre las profundas divergencias étnicas y sociales en las zonas de estudio $^{2}$. También usamos las declaraciones mencionadas porque en las averiguaciones sobre los prisioneros aprehendidos se tomaban con exactitud las palabras del declarante, por lo que reflejan sus expresiones y en algunos casos su forma de vivir y de pensar, así como sus ideas, dudas y decisiones ${ }^{3}$. Aunque los testimonios de los protagonistas estén sesgados por tratarse de declaraciones ante la autoridad, con un claro énfasis en que su participación en el bando insurgente había sido casual, éstos expresan su visión de los hechos. Se trata de testimonios de personas que el historiador escucha en raras ocasiones, como barberos, carpinteros, silleros, tejedores, operarios de minas e ingenios azucareros, carboneros, agricultores e indios campesinos, así como de gobernadores indígenas de pueblos cercanos a Taxco, Zacualpan, Sultepec, Tepecoacuilco, Iguala o Cuernavaca, entre muchos otros más. También se incluyen algunas opiniones de religiosos y de estratos urbanos medios que nos permiten hablar de conspiradores y de los motivos de un espectro social relativamente amplio de la participación en la gue$\mathrm{rra}^{4}$. A pesar de la riqueza de esos relatos, por la brevedad de este ensayo no se analizan con la profundidad que merecen, sino que sólo se pretende llamar la atención sobre fuentes que deben explotarse mucho más, en futuros trabajos.

\footnotetext{
${ }^{2}$ Véase Sánchez Santiró, 2001; Mentz, 1988; Martin, 1985; Mentz y Pérez López, 1998; Mentz et al., 1989, entre otros.

${ }^{3}$ Estamos de acuerdo con la crítica que de estas fuentes ha hecho Eric van Young, quien ha explicado, en su monumental trabajo sobre la guerra, los problemas metodológicos relacionados con las declaraciones que los aprehendidos como insurgentes dieron en la cárcel. Van Young, 2006, capítulo 2 y apéndice A.

${ }^{4}$ Los reos mencionados en este capítulo pasaron por Cuernavaca viniendo de los poblados cercanos o bajando de las montañas de Taxco, Zacualpan o Sultepec. Eran cientos de presos que habían seguido a los insurgentes en gran medida por voluntad propia, o que de manera accidental se habían encontrado en los lugares donde se desataron batallas y fueron conducidos a la cárcel de Cuernavaca. Véanse los cuadros 1 y 2.
} 


\section{INSURGENTES TOMAN CENTROS MINEROS Y FABRICAN CAÑONES}

Como consecuencia de la promesa hecha por el cura Miguel Hidalgo de que con el triunfo de la revolución cesaría el pago de tributos, el endeudamiento con "gachupines" y el gobierno de los "europeos", grandes contingentes de indios y gañanes se movilizaron después del 16 de septiembre de 1810 para "componer el reino", "poner al cura en su trono" y derrocar a los mentados "gachupines", como se expresaban los mismos protagonistas ${ }^{5}$. En los días y meses posteriores, mientras en el Bajío y en la zona de Toluca se levantaban en armas indígenas, rancheros y algunos hacendados, otros contingentes de insurrectos se organizaban bajo las órdenes de propietarios mineros o hacendados en los centros mineros de Amatepec, Tlatlaya, Sultepec y Zacualpan (véase mapa 1). Estos reales abiertamente apoyaron a los insurgentes, y durante años esa amplia zona rica en plata permaneció parcialmente en manos de los insurrectos. Se trata de poblados enclavados en las sierras y alejados de las grandes rutas comerciales —es decir, de los caminos hacia tierra adentro, Veracruz o Acapulco-. En cambio, en el real minero de Taxco, bien comunicado con la capital y donde vivían las autoridades y las familias más poderosas de la zona, los bandos en lucha se alternaron en el poder.

El 20 de noviembre de 1810 un pequeño grupo insurgente entró a Taxco bajo el mando del propietario minero Manuel de la Vega. En ese momento, el temor y la confusión de las autoridades fueron grandes, como puede apreciarse en el relato de un funcionario subalterno, que años más tarde sería un reconocido literato: José Joaquín Fernández de Lizardi. La llegada de los rebeldes provocó la huida del subdelegado llamado Villegas de Bustamante, y quedó como encargado de Justicia Fernández de Lizardi, famoso posteriormente como poeta y escritor. En ese momento, sin embargo, nada más lejano había para este modesto funcionario que las letras o la poesía. Su papel era muy complicado, pues como confesaría después en su declaración (a inicios de 1811), Vega

\footnotetext{
${ }^{5}$ Quiénes eran estos "gachupines" será tema que abordaremos más
} adelante. lo impuso como "justicia" de Taxco, cargo que él no deseaba, pero como se ordenó que lo decidiera el vecindario y se organizó una junta general: "resultó que desde el cura párroco hasta el último plebeyo me eligieron a mí, a pesar de mis muchas resistencias", y así tuvo que asumir el cargo ${ }^{6}$.

Sin embargo, una vez que salió el comandante insurgente, todavía en 1810, Fernández de Lizardi se vio en graves aprietos. Según su informe, la población de Taxco estaba francamente a favor de los insurrectos, pues con trabajo impidió que se repicaran las campanas a la entrada de los insurgentes, pero no podía evitar que los habitantes barrieran y regaran las calles. "Así estaba, señores, la plebe de Taxco", decía en su defensa cuando se le acusaba de no haber apoyado suficientemente a los realistas en la lucha y de no haber mandado las siete cargas de pólvora existentes en Taxco a la hacienda de San Gabriel, desde donde el comandante realista Andrade le había exigido que las remitiera bajo la custodia de algunos taxqueños. Fernández de Lizardi explicaba que no había podido enviar la pólvora porque los "plebeyos" de Taxco no eran de confianza y la entregarían de inmediato a los insurgentes. Cuando recibió la orden de enviar la pólvora, leyó ante escribano la orden frente a los taxqueños, pero:

aquella plebe decidida, luego que entendió a qué se dirigía, se marchó, sin quedar uno delante; sin embargo, de mis públicas insinuaciones y persuasivas instancias, ¿qué hombre de juicio atribuirá señores, a defecto mío, la insurgencia de la plebe? [...] ¿debía yo creer que los indios de los pueblos, que habían de transitar los conductores de dicho efecto, los dejarían pasar pacíficamente, cuando lo que a mí me constaba era que el correo semanario no llegaba a Taxco, no menos el mandatario de Tepozotlán? Y si un hombre con una valija y otro con un libro no se atrevían a pasar por semejantes pueblos, ¿cómo debía yo creer pasarían... con seis o siete cargas de pólvora? ${ }^{7}$

Agregaba que en la junta "los pocos decentes se excusaron unos con su edad avanzada, otros con sus enfermedades, otros con no poder desamparar a sus familias".

\footnotetext{
${ }^{6}$ Archivo General de la Nación (AGN), Criminal, volumen (v.) 204, folio (f.) $305 \mathrm{v}$.

${ }^{7}$ AGN, Criminal, v. 204, f. 303
} 
Mapa 1

30

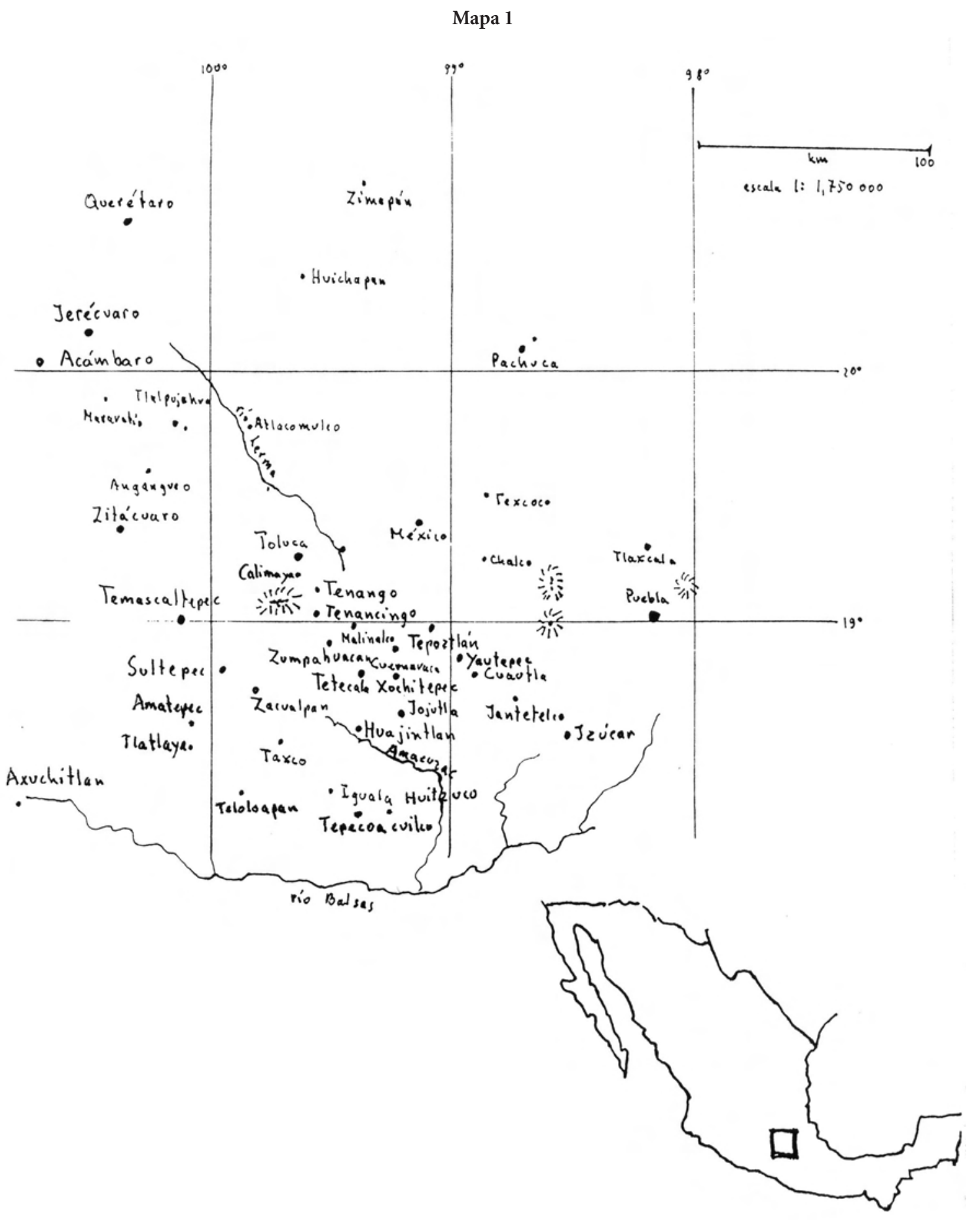


Dos individuos se ofrecieron, y "no hallándolo por ningún dinero, temieron que los insurgentes supiesen su oferta y se fugaron”. Como después Vega regresó, la pólvora quedó en manos de los insurrectos. Posteriormente, las tropas del rey recobraron Taxco y entonces, ya en 1811, se enjuició a Fernández de Lizardi y se le encarceló en la ciudad de México. Algunos curas de Taxco y el subdelegado, que efectivamente habían abandonado el real de minas en noviembre del año anterior, confirmaron la veracidad de las declaraciones del preso. Además, como el mismo Manuel Villegas de Bustamante fue su fiador, el futuro poeta y escritor salió de la cárcel ${ }^{8}$.

Independientemente del destino particular de esta autoridad de Taxco en aquellas turbulentas semanas, también a los funcionarios indígenas les fue difícil lidiar con ambos bandos en guerra, que imponían sus exigencias y castigos sin misericordia. En Tepecoacuilco se libró una batalla a inicios de diciembre, triunfaron los realistas y los gobernadores indígenas de Huitzuco y Tepecoacuilco fueron pasados por armas e incluso mutilados. La población y las autoridades enfrentaban momentos cruciales y difíciles, como puede apreciarse en varias declaraciones que se refieren al teniente de Justicia en Tenancingo o en Tlaquiltenango (véase cuadro 1, núm. 13; cuadro 2, núms. $46,47,82)$ y a la "República" o los gobernadores de algunos pueblos de indios como Axuchitlan, Iguala, Zacualpilla, Xochitepec, Jiutepec y Jerécuaro, entre otros (veáse cuadro 1, núms. 13, 14, 27, 28, 44; cuadro 2, núms. 63, 86, $88,90)$.

Así, aunque el ejército realista marchó a Taxco y recuperó el real minero, en los alrededores se siguieron librando combates durante noviembre y diciembre. Para ello, los mineros insurgentes aprovecharon sus conocimientos y habilidades. Bajo la dirección del propietario y minero José Romero, fundieron cañones en Zacualpan - como relatan los participantes, cuyas declaraciones reunimos en el cuadro $1-y$ atacaron varias veces tanto el real de Taxco como las poblaciones de Iguala y Tepecoa-

\footnotetext{
${ }^{8}$ Un año y medio más tarde, Villegas solicitó que se le cancelara la fianza. En 1812 se le volvió a abrir proceso a Fernández de Lizardi por un artículo en la Gaceta, pero otra vez fue puesto en libertad en diciembre de ese año. Véase Miquel i Vergés, 1969: 195.
}

cuilco. Incluso, en algunas confesiones se habla de un "castillo" fabricado en Iguala desde donde se dispararon los cañones y en el cual habían colocado una virgen (véase cuadro 1, núm. 44). Hay que subrayar las capacidades metalúrgicas de los técnicos y operarios mineros, pues contrastan con la escasez y prácticamente ausencia de herramientas de metal entre los habitantes de los pueblos del agro novohispano. A diferencia de los campesinos, los operarios de minas y haciendas de metales tenían práctica en el manejo de explosivos, metales y herramientas 9 .

Las élites regionales estaban divididas y fueron numerosos los curas y propietarios o administradores de empresas mineras cercanas a Taxco, y los vecinos instruidos como Lizardi, que simpatizaban con el movimiento, en contraste con algunos propietarios de Taxco, que trataban de que el real fuera un bastión leal al virrey. Ese contraste al interior de la clase de propietarios se explica por las profundas rivalidades entre los dueños de minas, ya que algunos — probablemente la familia Anza — recibían un trato preferencial de las autoridades y con frecuencia estaban exentos de impuestos y erogaciones que para otros empresarios menores significaban mermas sustantivas ${ }^{10}$. El real quedó en manos realistas hasta fines de 1811, cuando llegaron las tropas insurgentes de Hermenegildo Galeana, quien retomó el poblado. El mismo José María Morelos entró a Taxco en enero de 1812 y mandó fusilar al defensor de la zona y de la plaza, Mariano García y Ríos, y a los realistas y grandes propietarios. Solamente se salvó José Vicente de Anza, quien a cambio de su vida tu-

\footnotetext{
${ }^{9}$ Expertos mineros insurgentes como Casimiro Chovell, administrador de la mina de Valenciana, y Bernardo Chico, hijo de propietarios de minas y haciendas, fueron de gran importancia para conducir los primeros combates en Guanajuato. Técnicos mineros como el experto Valencia, citado por Humboldt, y alumno predilecto de Andrés del Río, los hermanos Rayón en la zona de Tlalpujahua y luego Sultepec y Temascaltepec, así como Dávalos en Guanajuato, fueron los que pudieron fundir cañones para los insurgentes. Fue el arma de fuego más relevante en todos los años de lucha. Así, también es comprensible que el batallón de Guanajuato del ejército "grande" de Miguel Hidalgo tuviese a su cargo la artillería.

${ }^{10}$ Ese trato desigual de grandes y poderosas compañías mineras de "gachupines" está claramente documentado para Zacatecas (véase más adelante, en el tercer apartado de este artículo, cómo Calleja percibe el descontento en ese real), pero la historia económica y minera detallada de Taxco aún está por escribirse.
} 
vo que dar al "Generalísimo" y a su causa toda su riqueza (al parecer cerca de 200000 pesos). En un escrito, Anza relató a sus herederos que fue con un operario minero y un mozo a colocar explosivos con la intención de provocar un gran derrumbe, para que las ricas vetas de sus minas, que empezaba a explotar, quedaran sepultadas para sus herederos, a la espera de mejores tiempos ${ }^{11}$.

Muchos habitantes del medio rural alrededor de Taxco probablemente apoyaban a los insurgentes, pero estaban entre dos fuegos y en sus declaraciones se puede apreciar que ambos bandos usaron el método de leva forzosa de manera violenta e indiscriminada; por tanto, es difícil saber lo que pensaban los indios, mulatos y mestizos pobres de poblados pequeños. Sin embargo, los momentos en los que fueron aprehendidos nos pintan un cuadro vivo de las fortuitas circunstancias que condujeron a que finalmente se les considerara sediciosos. Por ejemplo, un tejedor de Taxco llamado José Tomás Sevilla, al declarar en la cárcel, relata su experiencia en Zacualpan y Taxco en febrero y marzo de $1811^{12}$. Explica que fue a vender a Zacualpan unas mantas y que el teniente de insurgentes de der para que no divulgara que había visto que estaban fabricando unos seis o siete cañones. Aunque logró salir de la cárcel, no podía irse del poblado "porque no tenía pasaporte, ni había por dónde huir”. Otro declarante aprehendido se refiere a uno de esos cañones — al parecer no muy efectivo, pues su carga de plomo y clavos no hirió a nadie- y las siete cargas de pólvora que mencionaba Fernández de Lizardi en Taxco, al hablar sobre la guerra desde el "castillo" de Iguala (véase cuadro 1, núm. 44).

Cuando los insurgentes marcharon de Zacualpan hacia Taxco para atacar el real, dejaron arrestado al tejedor en casa de don José Romero; luego del ataque lo volvieron a encarcelar. Posteriormente, lo llevaron a un campamento del cual logró escapar, y regresó a Taxco porque

\footnotetext{
${ }^{11}$ Relación histórica del mineral de Taxco, 1925. Copia del informe original del señor don José Vicente de Anza de las minas del cerro de Compaña, Taxco (1814). En: Sociedad Científica "Antonio Alzate", Memorias, t. 46, (1925) (documentos presentados por el ingeniero Luís Híjar y Haro, M. S. A. en la sesión de 6 de octubre de 1924, 40 aniversario de la fundación de la Sociedad Alzate), pp. 57-63.

12 AGN, Criminal, v. 45, expediente (e.) 12, f. 344-362.
}

ya no había guardia en los caminos. En Taxco se presentó ante el subdelegado y don José Ávila, comandante de las tropas reales, y les explicó que había estado preso en Zacualpan, pero lo encarcelaron y lo mandaron en la cuerda de reos a Cuernavaca y a México, sin motivo.

Diferente fue el destino del joven de 16 años Felipe de Jesús Méndez, minero mestizo que acompañó a su madre a ver a su marido (su padrastro), que se hallaba con los insurgentes en Iguala; que fueron "con el ánimo de volverse prontamente" pero como no le quisieron dar pasaporte, se dirigió a Sultepec, donde permaneció dos meses; que estuvo en casa de su madre, a la que visitaba cada dos o tres días Vega, el capitán de los insurgentes; y que lo único que le daban eran 2 reales, cuando Vega iba con la Molina; que de Sultepec huyó para presentarse con las tropas del capitán don Juan de Dios Villanueva, pero al llegar al real lo aprehendieron. Pero que "él no portaba arma ni era soldado. Sólo conoció de los principales insurgentes al capitán don Manuel de la Vega, al capitán Manuel Ortiz y a los sargentos Villalba y Aguilar"13.

Algunos de los personajes aprehendidos sin duda fueron combatientes del lado insurgente y sus historiales son largos, pues después de algún tiempo de militar por esa causa — recibir soldada y conocer distintos lugaresmuchos decidieron regresar a su tierra natal. También es probable que a muchos indígenas monolingües no les hayan tomado declaraciones en un momento tan complicado como 1811. Un tratante de Metepec, español de 31 años, relata los vericuetos por los que pasó al viajar por tierra caliente de la comarca de Sultepec, donde se le acabó el "principal" (su dinero), por lo que se metió "de esquelero" en el pueblo de San Juan Tetitla. De ahí los insurgentes lo mandaron llevar al pueblo de Amatepec, donde tenían su cuartel y donde estuvo dos días, y le daban 2 reales diarios. Al tercer día huyó, pero lo mandaron seguir y aunque trató de llegar a su tierra (Metepec), un capitán con 10 hombres lo aprendió en el camino, antes de llegar a Zacualpan, el domingo 3 de marzo, y lo llevaron al campamento cerca de Taxco; allí le dieron una lanza y lo pusieron de centinela. Advierte el declarante que

\footnotetext{
${ }^{13}$ AGN, Criminal, v. 45 , e. 12 , f. 355-355 v.
} 
"lejos de tener un real de ellos, antes salió perdiendo una mula ensillada y enfrenada que traía y se la cogieron".

En términos generales, si se observan los cuadros 1 y 2 , resaltan dos motivos de los combatientes de sectores populares para participar en la lucha: el atractivo salario diario de 2 reales o de 4 reales para los de a caballo (o el peso diario que les pagaban en el Bajío), y la obediencia a sus patrones (hacendado o empleador minero) o a los gobernadores del pueblo de indios, obediencia que denominaré lealtad vertical (véase, por ejemplo, cuadro 1, núms. 3, 4, 13, 14, 18, 27, 52 y 87). Esta lealtad está relacionada con la organización y la pretensión de una sociedad estamental de origen medieval, en la que las personas se consideraban, por naturaleza, de diferente "calidad", y estaban jerarquizadas por voluntad divina, debiendo los grupos trabajadores subalternos total obediencia y sumisión a sus señores o patrones, quienes a su vez los protegían y eran los únicos que podían portar armas. Al mediar entre Dios y los hombres, los religiosos gozaban de especial prestigio y eran quienes sabían distinguir entre el bien y el mal. Efectivamente, en la insurrección en la zona de Sultepec el papel de los curas fue especialmente relevante ${ }^{14}$.

Además de la obediencia, la leva, las amenazas y el terror fueron las prácticas comunes para reclutar adeptos por parte de ambos partidos. De manera que, sin duda, hay algo de verdad en la declaración de un cura de Taxco sobre los delitos de los reos indios de su zona (en manos de las autoridades de la ciudad de México), y concretamente sobre la conducta de los habitantes del pueblo de Tlaxmalaca cuando llegaron los insurgentes:

No es fácil descubrir la verdad; pero lo que puedo informar a Vuestra Señoría con toda la sinceridad que el caso exige, es, según me hallo instruido: que cuando una gavilla de éstos se acerca, o acaso intempestivamente sorprende algún pueblo

\footnotetext{
${ }^{14}$ También había trabajadores que por su cuenta buscaban persuadir a la población, como en Cacalomacan, Toluca, donde un operario minero llamado José María López levantaba a los habitantes de los pueblos a favor de la rebelión. Los domingos los exhortaba a "ver si salían de la iglesia algunos gachupines para cogerlos", pero en un combate contra las tropas del rey quedó gravemente herido de una cuchillada que le cortó la nariz y el labio, y fue hecho prisionero. AGN, Criminal, v. 168, s. n., f. 249.
}

de aquéllos [indios], los amedrenta con las más terribles amenazas si no se prestan a seguir su inicuo partido; $y$ aunque hay muchos que lo hacen gustosa y voluntariamente; pero estoy en el concepto de que en la mayor parte entran compelidos del temor: con cuya consideración soy de sentir que tanto cuanto son acreedores al castigo los revoltosos, lo son a la piedad de Vuestra Señoría los miserables indios; porque a más de su natural pulsaminidad, me parece los disculpa en gran parte su conocida rusticidad: en esta inteligencia la bondad de Vuestra Señoría resolverá lo que en el particular estime conveniente que será lo más justo. Nuestro Señor santifique la vida de Vuestra Señoría, Real de Minas de Tasco, junio 10 de 1811. Miguel Pacheco Solís ${ }^{15}$.

Durante dos años, toda la región se convirtió en zona de guerra, pues los insurgentes tomaban ciertas plazas, para luego perderlas, recuperarlas, y así sucesivamente. En enero de 1811 el capitán realista Cosío informó que lo habían atacado los insurgentes de Tepecoacuilco. Éste era el poblado de mayor importancia para toda la zona indígena nahua hablante desde las montañas de Huitzuco hasta el río Balsas, y el jefe insurgente de esa región era Hilario Estrada. Se trató de una de las numerosas batallas que tuvieron lugar en esta zona. El capitán realista también tomó Iguala y permitió una hora de saqueo ${ }^{16}$.

A fines de 1811 los insurgentes, bajo el mando de Galeana, volvieron a tomar el poblado, defendido por Pedro Quijano. Los fusilamientos, los saqueos y las violaciones a las mujeres sin duda contribuyeron a profundizar el antagonismo entre la población y las tropas del virrey, asî como el odio entre los partidos combatientes. Todo ello muestra cómo, a pocas semanas de estallar la revolución armada, iba escalando la violencia. Por ejemplo, los realistas empezaron a exhibir los cuerpos o las cabezas de los insurgentes derrotados para escarmiento de la población. Así sucedió con la cabeza del dirigente insurgente

\footnotetext{
15 AGN, Criminal, v. 45,12 , f. 367 v.

${ }^{16}$ Los días 3 y 12 de marzo los insurgentes atacaron nuevamente Taxco, pero logró sostenerse el defensor del real, Mariano García y Ríos. Se informa que los atacantes venían bajo el mando de Francisco (probablemente Félix) Rodríguez, quien junto con los hermanos Ortiz dirigía a los insurgentes de la zona de Sultepec y Zacualpan. En esos días de marzo las tropas del rey hicieron expediciones por parte de los realistas hasta Teloloapan y tomaron a numerosos prisioneros. Los aprehendidos (véase cuadro 1) precisamente son testigos de lo sucedido en Taxco en los primeros días de los combates en ese real.
} 


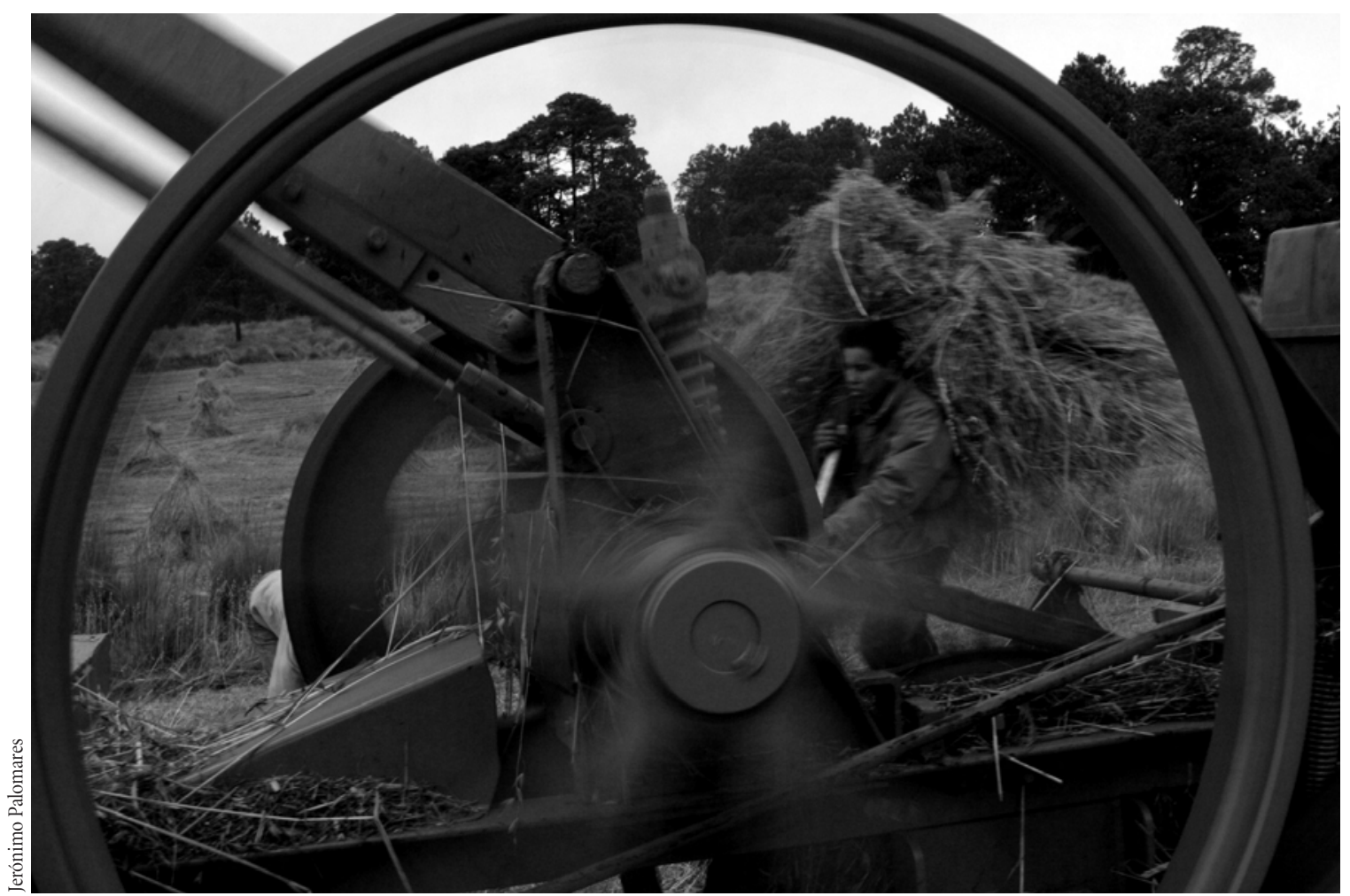

A vuelta de rueda.

Ignacio Rubalcaba, que había tomado los pueblos al poniente de Cuernavaca en noviembre de 1810. Posteriormente, los insurgentes también exhibieron cabezas de "gachupines".

En marzo de 1811 entraron los soldados realistas a Temascaltepec, donde operarios mineros, labradores y carboneros habían apoyado a los insurgentes. Se cometió todo tipo de atrocidades. Por ejemplo, el alcalde del pueblo de San Mateo fue fusilado y colgado de un árbol en medio del camino con un cartel al pecho que decía: "Por traidor a Dios y al rey" (Ortiz Escamilla, 1997: 218-219). El historiador conservador Lucas Alamán relata que en Toluca, a fines de 1811, el comandante realista Porlier mandó fusilar a cien indios, "puestos en fila en la calle principal de Toluca, no dejando vivo más que uno solo, para que fuese a contar esta terrible matanza a sus compañeros" (Alamán, 1972, vol. 2: 252). Ya en 1812, la crueldad de ambos bandos era tal que Francisco Ayala, quien fue capitán de la Acordada y se había unido a los insurgentes en Tepecoacuilco, mandaba a Morelos las cabezas de sus prisioneros europeos. Esta práctica fue desaprobada por el jefe, quien le ordenó que las colocara en las poblaciones para escarmiento de los enemigos y para evitar que los habitantes se pasaran al bando realista (Hamnett, 1990: 191). Así, con la violencia, la inclemencia y la crueldad de las contiendas militares, cundía el terror. Los insurrectos mataban a "gachupines" y en algunos casos los descuartizaban; las tropas del rey fusilaban a colaboradores de los insurgentes y los ahorcaban en las plazas de los poblados o castigaban a todos los habitantes, como sucedió en el pueblo de Huajintlan, al sur de Cuernavaca, cuyos habitantes, niños y mujeres incluidos, fueron ahogados en el río Amacuzac (véase cuadro 2, núm. 87).

El sustento de las tropas rebeldes al mando de José María Morelos, quien para 1812 había retomado Taxco y sus alrededores, se explica por la gran cantidad de nume- 
rario y de plata que existía en los reales de minas novohispanos. Veamos por ello algunas de sus características y, en especial, las relaciones sociales que entablaban con sus alrededores.

\section{LOS REALES DE MINASY LAS REDES SOCIALES QUE LOSVINCULABAN CON SU ENTORNO}

La escasez de numerario en la Nueva España era muy grande. No hay que olvidar que, paradójicamente, en este reino, donde abundaba el mineral de plata y cuya moneda circulaba por varios continentes, en verdad era apremiante la falta de dinero contante y sonante. Entre los trabajadores de muchas regiones el trueque era común, y era frecuente también el endeudamiento de los sectores subalternos en las tiendas y en las empresas agroganaderas o mineras.

En la economía novohispana, los reales de minas jugaban un papel central. Eran ciudades desde donde operaban recaudadores de impuestos y siempre había numerario, ya sea en dinero o en barras de plata. Asimismo, mantenían un arsenal importante de pólvora - como vimos en el caso de Taxco- y había dinero y plata labrada en casa de los ricos propietarios (o de sus administradores). Es con el dinero de esos centros mineros (además del botín de los saqueos) que se pudo financiar la guerra de los insurgentes. Recuérdese que la toma de Guanajuato por los rebeldes fue de gran trascendencia, pues así pudieron hacer un mayor acopio de alimentos, de pertrechos como pólvora, acero y herramientas de hierro, así como de plata labrada y en moneda. Se reportaba que en esa ciudad minera los insurgentes encabezados por el cura Hidalgo habían obtenido como botín 160000 pesos en moneda de plata, 32000 pesos en onzas de oro y 309 barras de plata. Cada una contenía 135 marcos y valía 1100 pesos, cantidad equivalente, por ejemplo, al salario anual de un director de una empresa minera, o al salario de cuatro años de un operario minero. Aparte, de los fondos que tenía la ciudad para administrar la provincia obtuvieron 38000 pesos, y del Cabildo de la ciudad 33 000. Por último, de la minería y de los depósitos consiguieron 20000 y 14000 pesos, respectivamente; de la renta de tabacos, 14 000, y algo más de 1000 pesos de la renta de correos. O sea, aproximadamente 620000 pesos (Alamán, 1972, vol. 1: 265). Guanajuato era una de las ciudades más pobladas de la Nueva España, pues contaba con más de 30000 habitantes, sólo precedida en todo el reino por Puebla, Guadalajara y la capital (Alamán, 1972, vol. 1:262) ${ }^{17}$. Concentraba a muchos propietarios de minas y haciendas, a comerciantes, a numerosos artesanos y arrieros, y a grandes contingentes de asalariados.

Para explicar el odio generalizado de la población rural hacia los propietarios de minas más poderosos, como en Taxco, es importante el hecho de que este centro minero se vinculaba estrechamente, como todos los demás, con un hinterland agrario, así como con los pueblos alejados de donde provenían los indios de "repartimiento" (esto explica, por ejemplo, la íntima relación de Guanajuato con los pueblos de Michoacán). El "repartimiento" de indios para la minería había causado gran descontento en el medio rural durante todo el siglo XVIII. Se trataba de un reclutamiento forzado: en época de bonanza, y con los privilegios otorgados por el virrey a ciertos inversionistas mineros, se obligaba a los pueblos designados a mandar un porcentaje de trabajadores temporales a las minas de esos propietarios o de una compañía favorecida. Generalmente realizaban las faenas, el trabajo en obras muertas o en el desagüe (Mentz, 1997). En estas relaciones con su hinterland de productos agrarios y de fuerza de trabajo se daban todo tipo de conflictos por retribución injusta de productos (maíz, carbón, sal, jarcia, maderas, etc.) y por retención de operarios debido a su endeudamiento. El descontento venía de décadas atrás, y se expresó en cuantiosas quejas y numerosos tumultos, como puede apreciarse en el mapa 2 , en el que se resumen algunos de estos eventos. El mapa muestra el gran descontento acumulado contra los reales de minas, donde tenían sus empresas los ricos "gachupines" que lograban obtener privilegios y que, además, habían impuesto a su propio virrey en 1808 .

\footnotetext{
${ }^{17}$ Alamán incluye todos los campamentos mineros alrededor e informa que Guanajuato tenía más de 70000 habitantes.
} 
Hay que subrayar que eran los "gachupines", como Pedro Romero de Terreros o el ya mencionado José Vicente de Anza y sus socios en Taxco, los que habían recibido de los virreyes exenciones de impuestos y demás privilegios, a diferencia de los propietarios menores (Anza, además, era socio de los Fagoaga en el real de Huautla). Las minas de Anza en Taxco acababan de iniciar su bonanza. Esas exenciones se autorizaban sólo al grupo más poderoso y rico de la oligarquía, lo cual mostraba la inequidad del sistema político y fiscal, y exacerbaba rencores de los distintos sectores sociales contra los privilegiados, que a su vez evadían impuestos y sobornaban a los oficiales reales. Para colmo, un grupo de ellos había dado un golpe de Estado. Así lo percibía con indignación la mayoría de los propietarios menores de las provincias. Si consideramos los pueblos del hinterland de los reales de minas y la cantidad de personas involucradas en la minería, el número de inconformes era grande, pues éstos no eran sólo quienes vivían en un real, en una mina o en una hacienda de beneficio, sino que la industria involucraba a amplios círculos sociales - muchos de ellos indígenas de las zonas más apartadas - que de una u otra forma estaban sujetos, en especial en las empresas de los "gachupines" privilegiados por el virrey ${ }^{18}$.

Así, los gritos de “iMuera el mal gobierno y viva el rey!” " “ ¡Viva el rey de los cielos y muera el rey de España y los gachupines que echan a perder la tierra” se habían escuchado ya vigorosamente en la segunda mitad del siglo XVIII en distintos reales. Como reporta Felipe Castro, en esos tumultos participaron conjuntamente miles de operarios y varias personas "de respeto"(Castro Gutiérrez, 1996: 159). Esto nos muestra que había pugnas al interior de la clase dominante, así como antagonismos clasistas, desde varias décadas antes de 1810, y que lejos de vivir el reino una paz idílica, como quiere hacernos creer

\footnotetext{
${ }^{18}$ Se repiten con frecuencia las cifras estimadas de máximo 28000 a 51000 personas ocupadas en la minería novohispana (Brading, 1975: 39; Humboldt, 1966: 48), pero necesariamente habría que incluir a todos aquellos que temporalmente tenían que trabajar en las minas, a los que abastecían con sus productos a minas y haciendas de metales y también a los amplios círculos de personas que estaban de manera indirecta relacionadas con la producción de plata y dependían de su coyuntura.
}

Lucas Alamán, las tensiones sociales en estos centros industriales eran frecuentes. Quizá quienes no habían gritado "mueras al mal gobierno" por temor a represalias, o sus descendientes, fueron probablemente quienes en 1810 se levantaron en armas o simplemente obedecieron a sus patrones insurgentes o a los gobernadores de sus pueblos, y los siguieron con cierta convicción de hacer lo correcto.

En el mapa 2 se puede apreciar que el hinterland de fuerza de trabajo reclutada por medio de la coerción de los reales mineros era extenso. Los lugares de abasto de maíz, sal, cueros y carbón cubrían un área bastante amplia. Sin embargo, no estaban tan distantes de los reales por los altos precios del transporte. De tal forma que, en nuestra zona de estudio de Taxco-Sultepec, por ejemplo, los que abastecían de maíz eran las haciendas cercanas y los pueblos de indios de Iguala y Tepecoacuilco, hasta del río Balsas y sus afluentes al norte. Los pueblos de Alahuistlan y San Miguel Ixtapan eran proveedores de sal; los de Coatepec-Ixtapan proporcionaban la harina de trigo necesaria, mientras cueros, carne, quesos, azúcar y todo tipo de ganado provenían de los valles de Teloloapan y de las jurisdicciones de Cuautla y Cuernavaca (véase mapa 1). Por eso, los habitantes de esas regiones mantenían relaciones comerciales y sociales intensas. Hay que considerar por otra parte las redes que se tejían específicamente entre los grandes propietarios de minas, haciendas, ranchos y bienes urbanos. Por lo general, ellos residían en la ciudad de México y no donde operaban sus empresas, y como tenían numerosos administradores y sirvientes, los mandaban de un lugar a otro con frecuencia. Entre la élite de Taxco, por ejemplo, figuraban en 1810 Gregorio de Aramburu, Juan del Corral, Manuel de Ávila, José de Tellechea y José Vicente de Anza. El último explotaba en ese momento con éxito las vetas Compaña y Archuleta y, como se dijo, fue el único que quedó con vida después de entrar Morelos en el real. Al analizar a esas familias inversionistas en la minería, simultáneamente hay que estudiar a sus "aviadores", los comerciantes-banqueros que los financiaban. Aparte, se encuentra uno a menudo a sus parientes o socios en otros reales mineros. Así, los Anza sobresalen no sólo en Taxco, sino también en Huautla y Zacatecas; Antonio de Bassoco en Zacatecas y Durango; 
Mapa 2

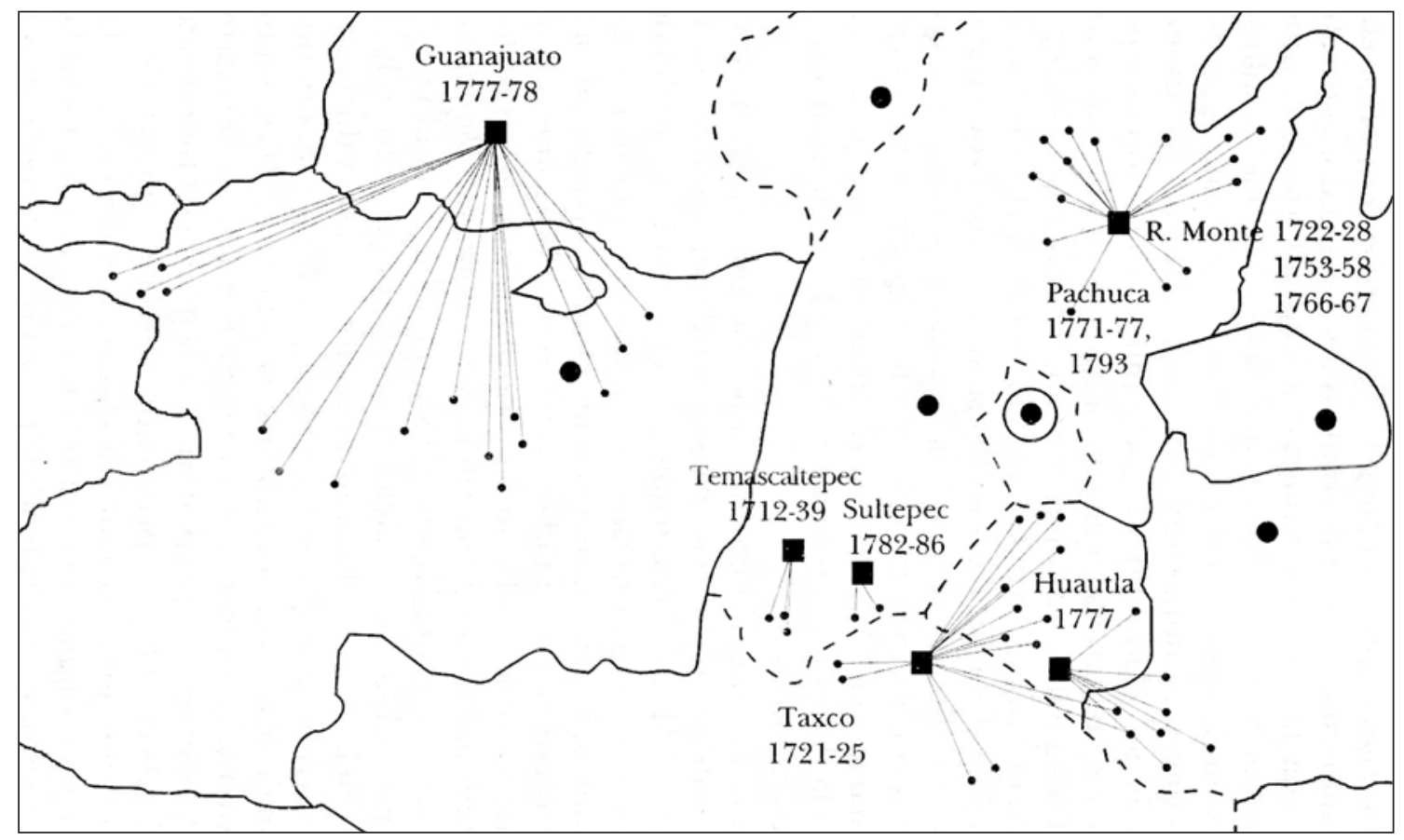

Fuente: Elaboración propia.

los Fagoaga, con sus ricas minas de Sombrerete, tenían inversiones en Zacatecas, pero también en Sultepec o en Huautla, y así sucesivamente. Los inversionistas en el ramo minero muchas veces lo eran en distintos y distantes reales de minas ${ }^{19}$.

Diferentes eran las redes sociales tejidas por los sectores medios o altos, entre los que encontramos dueños de unas minas y una hacienda de beneficio, o solamente de unas minas, o sólo de una fundición o de una pequeña hacienda de beneficio, transportistas — dueños de recuas de mulas, como el padre del cura Mariano Matamoros-, comerciantes menores y rescatadores de plata (comerciantes del mineral), dueños de prósperas hacien-

\footnotetext{
${ }^{19}$ Sin embargo, entre la oligarquía novohispana ligada a esos nombres había profundas diferencias políticas desde 1808. J. M. Fagoaga y el Marqués de Rayas, por ejemplo, participaban activamente en las conspiraciones proindependentistas. Los vínculos conspiratorios del último llegaban hasta Mérida.
}

das de labor o de ganado, y de ranchos grandes. Los hijos de este grupo por lo común encontraban ocupación en las empresas de sus padres y algunos ingresaban al sacerdocio, por lo que no sorprenden las amplias redes que existían entre los religiosos, jóvenes y viejos, ya sea del clero secular o regular ${ }^{20}$.

Los hijos de propietarios mineros de nuestra zona de estudio se formaron en colegios de las capitales provinciales, en la universidad de la capital o en los seminarios regionales, como el de San Nicolás, en Valladolid, desde donde el cura Miguel Hidalgo había ejercido gran influencia como maestro y rector. Además existían amplias redes de parentesco, lo que tal vez explique el gran tejido

\footnotetext{
${ }^{20}$ Algunos ejemplos de las clases intermedias — no los más ricos, ni los más pobres - en la Nueva España, sus propiedades y familias se analizan en Mentz, 2003. En esos estudios de caso se percibe con claridad la importancia de las carreras eclesiásticas de los vástagos de esas familias.
} 
de curas proinsurgentes, en especial en las zonas de Toluca, Temascaltepec, Sultepec y Zacualpan. Esto se comprueba en el caso del mismo cura Hidalgo, quien por parte materna tenía numerosos familiares en Sultepec, donde fungieron como líderes locales sus primos hermanos Mariano y Tomás Ortiz. Otro religioso de la zona era José Antonio Gutiérrez, originario de Metepec y cercano a los hermanos Ortiz, quien había sido "insurgentísimo" — - según rezan informes anónimos encargados por el gobierno realista - desde los primeros días de la rebelión. Como reporta Van Young, se decía que Gutiérrez era "declarado enemigo de los europeos", había ganado a mucha gente para la causa insurgente y tenía a su mando una fuerza de indios. Años más tarde, fue párroco en Alahuistlan mientras vivía en Toluca y un vicario se encargaba de su parroquia. Con la fuerza del lenguaje de denuncia del momento, se afirmaba en el informe anónimo sobre Gutiérrez que su perversidad era tal que sus arengas públicas contra el régimen anulaban los esfuerzos de diez curas leales: "En suma este cura, en odio a los europeos y afecto a la revolución, es otro Hidalgo [o] Morelos... capaz de destruir mil reinos" (cit. en Van Young, 2006: 469-470) ${ }^{21}$.

También destacaban como partidarios del movimiento revolucionario en 1811 los mercedarios del convento de San Antonio, en Sultepec. El fraile Pedro Flores se describía como "afectísimo a la insurrección", y como insurgentes "tímidos" se define a los padres Pérez y Salazar, del mismo convento (Van Young, 2006: 464-465) 22. Vemos así la relativa capacidad de persuasión de los familiares o curas cercanos a Hidalgo, misma que aprovechó el dirigente de Dolores desde épocas de la conspiración de Querétaro, pues mandó cartas a gran cantidad de religiosos de ciudades y pueblos, anticipando la revolución y planeando que tomaría la ciudad de México el 1 de noviembre. De este modo, llegaron mensajeros indígenas (los otomíes del Bajío deben haberse encargado de la difusión de las cartas) a muchos lugares alejados, inclusive a Cuernavaca, como veremos más adelante.

\footnotetext{
${ }^{21}$ Posteriormente Gutiérrez fue tesorero de los insurgentes y diputado en el Congreso Insurgente de Chilpancingo.

${ }^{22}$ También relata este historiador cómo el mercedario José Montenegro había "alucinado" a los jóvenes de ese lugar.
}

La personalidad del cura Hidalgo atrajo a un número considerable de religiosos hacia su causa, por sus redes de parientes, exalumnos y colegas en lugares lejanos. Todos ellos eran figuras de autoridad en esta sociedad estamental: intelectuales del medio rural novohispano, los que sabían leer y escribir, y que cada domingo podían difundir en misa sus ideas, tanto religiosas como políticas. En ese sentido, eran las personas más respetadas conforme a la visión estamental-medieval predominante: mediaban entre la sociedad y Dios, sabían lo que eran pecados y virtudes, eran los expertos en distinguir entre el bien y el mal.

Para comprender el hecho de que comandantes insurgentes se hayan valido de numerosos religiosos como sus asistentes, es fundamental señalar que en el medio rural escaseaba la gente que sabía leer y escribir. Hermenegildo Galeana, por ejemplo, rico hacendado de Zacatula, en la costa, y excelente militar y estratega de José María Morelos, no sabía leer ni escribir. También eran analfabetos muchos comerciantes, rancheros y operarios calificados, o tenderos, como los de San Francisco Tetecala. La importancia que adquirieron los sastres o barberos alfabetizados, o un joven de Zinapécuaro de 19 años sin oficio entre las huestes del ranchero Rubalcaba sin duda se debe a que sabían escribir y se les podía dictar cartas y oficios (véase cuadro 2, núms. 64 y 89, y 48 y 63). Durante la guerra, esa habilidad era fundamental para llevar el registro de la gente, los pertrechos y el botín adquirido; y para los comunicados con otros comandantes, sólo por enumerar unos ejemplos ${ }^{23}$.

En zonas mineras alejadas también se hizo sentir rápidamente la insurrección contra los "gachupines", como sucedió en Tlatlaya, donde destacó la participación del cura local, y cerca de Amatepec, donde los insurgentes tenían campamento en 1811, como lo informa un declarante. El párroco suplente de Tlatlaya, José López Cárdenas, oriundo de Sultepec, cuando comenzó la insurrección de Dolores leyó desde el púlpito de su iglesia un edicto del

\footnotetext{
${ }^{23}$ José María Morelos se refiere mucho a la necesidad de contar con gente en los ejércitos que supiera leer y escribir, en una carta a Rayón, septiembre de 1812, en Guedea, 1995b: 82. Sobre los Galeana, véase Hernández Jaimes, 2002.
} 
padre Miguel Hidalgo en el que se ordenaba a los parroquianos construir una trinchera o cerco para defender al pueblo de un posible ataque realista. Posteriormente, este entusiasta cura reunió públicamente fondos para celebrar algún triunfo del cura insurgente Morelos. Es decir, en este alejado pueblo había un gran entusiasmo por la causa rebelde, lo que explica que en Sultepec y los pueblos al sur (Amatepec y Tlatlaya) se establecieran campamentos insurgentes ${ }^{24}$.

Muchos jóvenes recién reclutados en el Bajío se sintieron animados para unirse a la Revolución por el hecho de que, en octubre de 1810, las autoridades religiosas rurales en Malinalco y Zumpahuacan aprobaron la insurrección, como leemos en sus declaraciones, al igual que los religiosos de Toluca. El entusiasmo rural a favor de la rebelión en esas zonas debe explicarse también por los conflictos entre los indígenas y las grandes empresas agrícolas y mineras ${ }^{25}$. Las declaraciones mencionan también a la "Santísima Virgen" y las alentadoras palabras de sacerdotes (véase cuadro 1, núms. 13 y 44). Informan los declarantes que habían seguido desde el Bajío al insurgente Rubalcaba, que en Toluca los habían tratado muy bien en el convento donde se hospedaron e igualmente un religioso en Malinalco (véase cuadro 2, núm. 74). Un joven de Jerécuaro, de 17 años, decía en su declaración, por ejemplo, "que no le parecía que era malo [marchar con los insurgentes], respecto a que por los más lugares donde transitó, como fue Acambay, le replicaron" (véase cuadro 2, núm. 64). Pero no debemos olvidar que había tanto religiosos prorrebeldes como prorrealistas (véase cuadro 1, núms. 13, 28; cuadro 2, núms. 47, 56, 63, 74).

\footnotetext{
${ }^{24}$ Van Young describe ampliamente las distintas actitudes de los curas proinsurgentes de esta zona. Sin embargo, en su interpretación general subraya que ellos no fueron más de $30 \%$ e inclusive menos, del total de sacerdotes novohispanos. Más que incitar a su feligresía, dice, la mayoría más bien la siguieron o pretendieron cierta postura favorable para conservar su control en localidades abiertamente rebeldes. Véase Van Young, 2006: 460-466 y 479.

${ }^{25}$ Desde antaño Zumpahuacán fue obligado a servir en las zonas mineras y en la segunda mitad del siglo XVIII en Malinalco se habían exacerbado los conflictos por agua entre los pueblos y la hacienda de Jalmolonga. Ésta también era propiedad del inversionista y golpista Gabriel J. de Yermo.
}

\section{CAMPESINOS CON HONDASY PALOS SE SUMAN A LA LUCHA. ¿QUIÉNES ERAN “GACHUPINES" EN LOS VALLES DE TOLUCA Y CUERNAVACA?}

A pesar de la retirada hacia el norte de Miguel Hidalgo y el "ejército grande" (como decían los participantes en la guerra), y de la represión por parte de las tropas del rey en los pueblos que habían apoyado a los "trozos" insurgentes en su paso durante el año de 1811, el apoyo abierto o clandestino a la Revolución en nuestra zona de estudio, incluyendo los valles de Toluca, no decayó. Entre enero y junio de 1811 los informes del comandante realista Gutiérrez al virrey mostraban desesperación: por ejemplo, al referirse a los enemigos en Cacalomacan, donde se enfrentaban los ejércitos, decía que "en los pueblos inmediatos comenzaron los indios a tañer las campanas, con gritería incomparable"; o hablaba de la inseguridad que se vivía en las cercanías de Santiago Tianguistenco, de Calimaya o de Metepec $^{26}$. El comandante siempre hacía referencia a la falta de armas de los agricultores, artesanos y operarios insurgentes que luchaban sólo con garrotes, palos y azadones. Especial mención debe hacerse de las hondas, sin duda el arma más socorrida en el campo. Datos etnográficos podrían sostener su amplio uso aún en la actualidad. Elaboradas de manera casera con fibras vegetales, las hondas formaban parte desde la niñez de los aperos de la gente del campo, aun de la más pobre. Con ayuda de ellas y con piedras cazaban conejos, derribaban aves, sacaban al ganado de sus milpas. Así, las piedras eran una verdadera arma y jugaron un papel vital en los motines, tumultos o rebeliones de la época. Obsérvense para nuestra zona de estudio las frecuentes menciones de piedras o garrotes, y la ausencia de armas entre los insurrectos - $\mathrm{O}$ los acusados de serlo- en el cuadro 1 (núms. 9, 24, 43), así como en el cuadro 2 (núms. 55, 77 y 85). Solamente en el caso excepcional de que hubiera hierro en una hacienda o rancho, se elaboraban precipitadamente unas lanzas para los gañanes, de tal manera que sí había improvisados "lanceros", sobre todo en las tropas preparadas por hacendados.

\footnotetext{
${ }^{26}$ AGN, Operaciones de Guerra, vol. 402, f. 15, 19 y 20.
} 


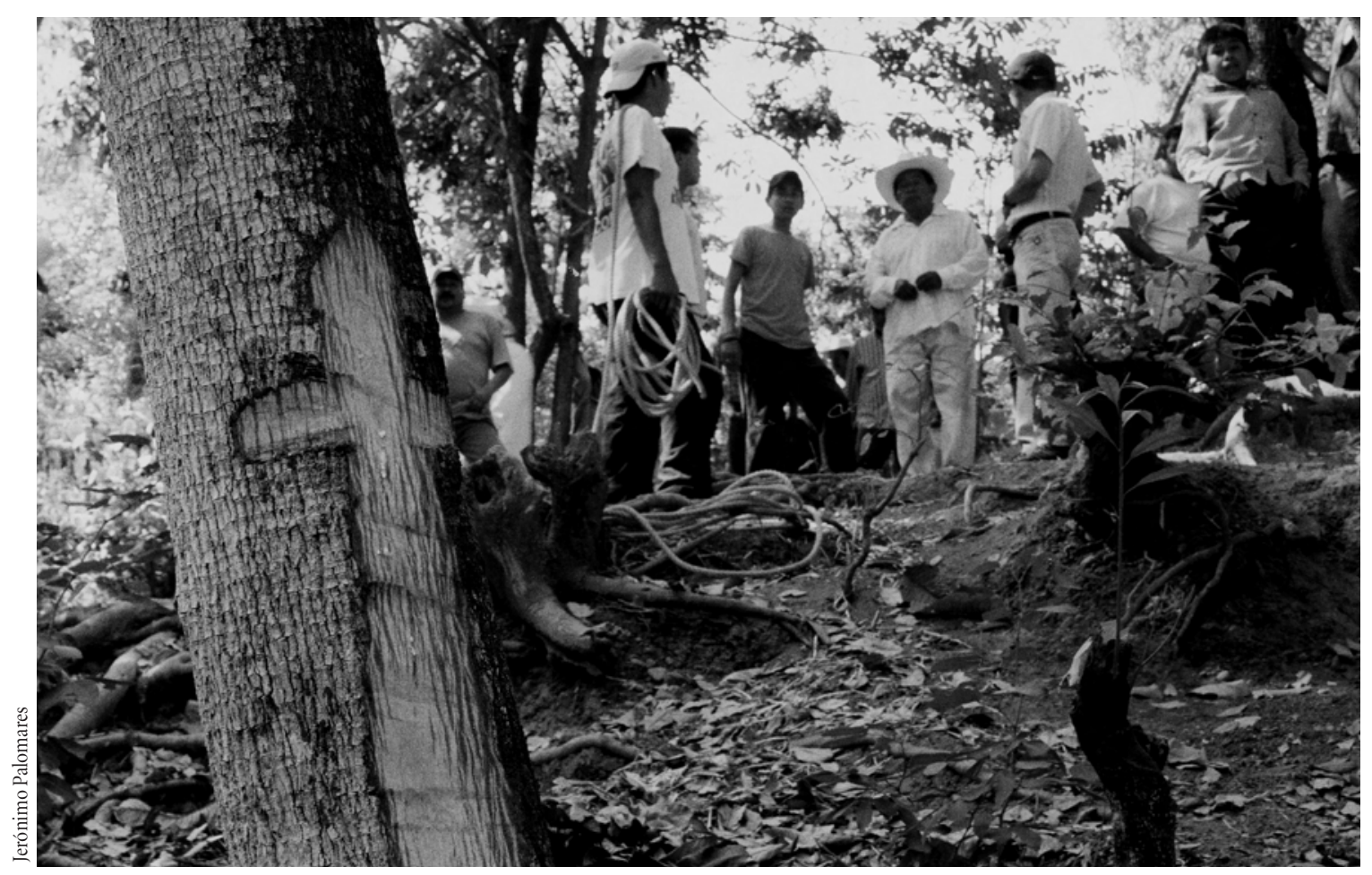

$40 \$ Venustiano Carranza, Chiapas, 2005.

Aunque el "ejército grande" de Hidalgo contaba con armamento e incluso artillería, los pequeños contingentes dispersos que luchaban en el centro y sur del país por la causa insurgente padecían la escasez de armas, como se comprueba en las declaraciones posteriores de muchos participantes (Ortiz, 1997: 47-48) ${ }^{27}$. En nuestra zona de estudio es evidente que miles de flecheros y honderos acompañaban a Morelos en diciembre de 1811 cuando atacó Chiautla o Izúcar, o después, cuando defendió Cuautla. Flechas, garrotes, hondas con piedras, o solamente piedras, fueron sus armas en las contiendas. Incluso llegó a ser impresionante, la habilidad de los protagonistas pueblerinos para elaborar parapetos de piedras y para atacar, desde el techo de sus casas, a las tropas realistas, como fue el caso de Izúcar, a fines de 1811,

\footnotetext{
27 Ortiz (1997: 47-48) opina que no hubo escasez de armas, pero en su estudio sobre todo sigue al ejército más importante de Hidalgo, en el que participaban numerosos soldados pertrechados.
}

donde fueron rechazadas por una "multitud de gente armada de piedras, hondas y flechas" que coronaba las azoteas de todas las casas circunvecinas (Alamán, 1972, vol. II: 276$)^{28}$.

La falta de hierro en los pueblos $-\mathrm{y}$ su abundancia relativa en empresas mineras o en haciendas que contaban con fraguas (herrerías) y cobre para los cazos (si eran azucareras) — se reflejó cuando los insurgentes llegaron a los poblados ubicados al poniente del actual estado de Morelos. Por las declaraciones de los reos sabemos cómo llegaron del Bajío varios grupos de insurgentes bajo las órdenes de Allende. Aunque este dirigente marchó en otra dirección, un grupo se separó y llegó por Tetecala a la hacienda de San Gabriel y a los demás pueblos y empresas azucareras del valle de Cuernavaca. Este grupo estaba

${ }^{28}$ Sobre los indios honderos en Cuautla, véase Ortiz, 1997: 326 y ss. Sobre la importancia que Morelos daba a los honderos y a la estrategia de subir la mayor cantidad posible de piedras a las azoteas véase Chávez Orozco, 1976: 77. 
encabezado por el ranchero de Jerécuaro Ignacio Rubalcaba, quien perdió la vida al entrar a esa villa (véase cuadro 2, núms. 46, 48, 50, 62, 63 y 64).

Aunque en Cuernavaca amigos de Miguel Hidalgo habían conspirado en favor de la insurrección entre septiembre y octubre de 1810 — sobre todo el cura y doctor Estanislao Segura, junto con algunos principales de la República de Indios-, en noviembre, en el momento del enfrentamiento abierto, cuando llegaron los "trozos" del ejército con "plebeyos" armados, el subdelegado de Cuernavaca Manuel de Fuica huyó pero el vecindario cerró filas en contra de los rebeldes ${ }^{29}$. Así, en la primera y única batalla abierta de este grupo insurgente en la entrada del sur de la villa, en Chipitlán, entre Temixco y Cuernavaca, murió el ranchero de Jerécuaro. Según se lee en las declaraciones, los "soldados de a caballo" que llegaban del Bajío con Ignacio Rubalcaba recibían un peso y los demás 4 reales diarios. Pero no tenían como armas sino palos, garrotes y hondas. En Tetecala, en los demás pueblos grandes y en las haciendas se saquearon las tiendas, que eran verdaderos paraísos para la gente humilde. En un caso sólo se robó la mitad de las mercancías, pues estaba en "compañía": una mitad era de un "gachupín" y la otra no. Nótese cómo era complejo para los mismos participantes distinguir entre los americanos y los gachupines. Sin embargo, en el pueblo Xochitepec, donde había una tienda de un europeo, la principal meta fue el hierro que ahí se guardaba, para labrar unas lanzas. Para ello un tendero local, simpatizante de los insurgentes, primero hizo una muestra de tejamanil, misma que luego copió el herrero del pueblo (véase cuadro 2, núm. 85). Según este artesano, cuando terminó de fabricar las lanzas casi se las arrebatan, pero él le entregó las tres que acababa de hacer al hijo del gobernador del pueblo.

En este pueblo de Xochitepec fueron tres los individuos que organizaron a los habitantes y participaron en

\footnotetext{
${ }^{29}$ Mayores detalles en Mentz, en prensa. El doctor Estanislao Segura, en una tertulia en Todos Santos, dijo que los insurgentes querían un gobierno criollo, que el virrey era un traidor y Yermo un pícaro, que hacía dos años que estaba gobernando el reino, "pues él ponía y quitaba virreyes, y que europeos habían dado ejemplo a los americanos para hacer lo mismo". AGN, Criminal, v. 39, 3, f. 143. Al doctor se le hizo un juicio de infidencia y terminó preso en la ciudad de México.
}

el intento de tomar la ciudad de Cuernavaca y la hacienda de Temixco: el tendero, el gobernador Pascual de los Reyes y su hijo Cirilo. Terminaron aprehendidos después de la batalla de Chipitlán, junto con los demás. En su declaración, explicaban que un indígena principal de Cuernavaca, probablemente miembro del Cabildo (la República de Indios) fue notificado por Rubalcaba de su llegada. También había precisado al gobernador de Xochitepec a no obedecer si los llamaban de parte del Juzgado de Cuernavaca. Que los insurgentes venían "destruyendo a los gachupines y dando tierras y aguas a los naturales”. Por esa razón el gobernador obedeció y apoyó a los insurgentes (véase cuadro 2, núm. 86). Los Reyes, el herrero y el tendero fueron condenados a presidio en La Habana.

Obsérvese cómo la promesa de adquirir tierras y aguas animó a los indígenas de los pueblos de esta zona a participar en la guerra; también se unieron sectores medios, como administradores, y aun hacendados azucareros que eran rivales del acaparador de aguas y tierras de la zona, Gabriel J. de Yermo. Pascual Reyes menciona en su declaración que el teniente de Justicia de Tlaquiltenango llegó con muchos indios de dicho pueblo; que participaban asimismo el gobernador de Atlacholoaya, los de Jojutla y alguna "gente de razón" de la hacienda de Treinta Pesos, entre otros muchos. Es decir, en ese momento había numerosas personas de sectores sociales muy heterogéneos convencidas de la bondad de la causa de buscar un gobierno "criollo", de los americanos, y combatir a los "gachupines" 30 .

Cabe subrayar las complejas relaciones sociales en el valle de Cuernavaca. Sus fértiles tierras irrigadas terminaron acaparadas por las haciendas azucareras, con las que los pueblos tenían graves conflictos por límites, por aguas, por montes y leña, como ha mostrado ampliamente la historiografía ${ }^{31}$. En Cuernavaca, los conflictos

\footnotetext{
${ }^{30}$ Mariano Valdovinos, enemigo de Gabriel J. de Yermo y su vecino, dueño de las haciendas de Treinta Pesos y San Miguel, apoyó a los rebeldes, como harían otros de la zona de Yautepec, quienes le enviaron a Morelos a Cuautla una porción de cobre en febrero de 1812.

${ }^{31}$ Durante el siglo XVIII, cuando la población había aumentado en las comunidades, también crecieron algunos ingenios azucareros. A fines del siglo, los miembros del consulado de comerciantes de la
} 
se dirigían sobre todo contra los intereses del latifundio Temixco-San Gabriel en manos de Gabriel J. de Yermo, pues desde 1803 proyectaba un gran canal de irrigación y los perjudicados, pueblos y hacendados menores, habían manifestado sus quejas y protestas en múltiples documentos (Mentz y Pérez, 1998: 11-44).

Los líderes insurgentes supieron aprovechar la necesidad de tierras y aguas de los habitantes de estos valles y su odio hacia los nuevos inversionistas modernizadores. Hay que mencionar la enorme diferencia existente entre los grandes emporios ganaderos-azucareros (también productores de aguardiente, cuyos impuestos eludían) en manos de comerciantes-inversionistas - como Temixco-San Gabriel en Cuernavaca y Santa Clara MontefalcoTenango en Jonacatepec- y las haciendas menores o ranchos prósperos. Por eso hay que hilar los argumentos con cuidado para explicar, en general, la solidaridad en la guerra contra los "gachupines" que se dio entre los grupos rebeldes y los hacendados menores, los administradores y empleados de ingenios azucareros, y los dueños de empresas mineras menores ${ }^{32}$.

Probablemente el término "europeo" o "gachupín", visto desde el punto de vista de los revolucionarios, deba ajustarse a personajes distintos según la zona. En general designa a los funcionarios reales de mayor rango, los recaudadores de impuestos, los inversionistas más ricos de la ciudad de México y los administradores europeos de sus grandes y ricas empresas. Sin embargo, en cada región hay que observar las variaciones locales, pues el nombre tiene que ver, sobre todo, con la postura política

ciudad de México concentraban en sus manos más de $60 \%$ de la producción de azúcar de Cuernavaca-Cuautla. Modernizaron la industria, establecieron fábricas de aguardiente y dominaron los canales de comercialización interregional e internacional. Como necesitaban tierras, aguas, leña, maderas y pasturas para hacer productivas sus empresas, su voracidad sobre los recursos fue notable. Aunque la resistencia de muchos pueblos y el apoyo legal recibido sin duda les permitió, en algunos casos, conservar sus antiguos territorios o recursos, en muchos otros, sobre todo en Cuautla-Jonacatepec, los perdieron. Véase Sánchez Santiró, 2001; Mentz, 1988; Martin, 1985; entre otros.

${ }^{32}$ Mariano Matamoros era cura de Jantetelco, pueblo rodeado precisamente por comunidades en conflicto contra el emporio "gachupín" de las haciendas Santa Clara y Tenango. Esa experiencia explica, quizá, que haya tomado el partido contra los europeos. Mayor discusión sobre el papel de los curas en Van Young, 2006: 460. que asumieron en ese momento. En la zona de Taxco proponemos que también lo eran los propietarios mineros y comerciantes más ricos, y en los valles azucareros, las familias de los ingenios más grandes (simultáneamente fábricas de aguardiente y empresas ganaderas), como en la zona de Cuautla-Jonacatepec la familia SalvideIcazbalceta-Musitu o la familia Michaus; o en Cuernavaca, la familia Yermo o el mismo gobernador del Estado del Marquesado del Valle o sus administradores ${ }^{33}$.

Hay que tener presente que en los últimos años del siglo XVIII se había acelerado la concentración de la riqueza en manos de grandes comerciantes-inversionistas. Para ellos, los ingenios azucareros, las fábricas de aguardiente, las haciendas cerealeras o ganaderas y las empresas mineras y demás bienes urbanos formaban parte de un conjunto mayor del total de sus inversiones. Además, entre esa oligarquía se encontraba el grupo que perpetró en 1808 el derrocamiento del virrey y que impulsó, a su vez, negocios propios muy jugosos. Sus rivales fueron, como observamos en nuestra zona de estudio, los propietarios de empresas menores, haciendas y ranchos, con raíces locales, y los sectores de profesionistas y religiosos, dirigentes a nivel provincial, que se oponían a aquel grupo de la oligarquía (los "gachupines"), el cual controlaba el numerario, los créditos, los privilegios y, desde el golpe de 1808, el poder político. Como decía el propio cura de Cuernavaca en una tertulia, los europeos mostraron cómo quitar y poner virreyes, y ahora eso mismo harían los americanos.

En ese sentido coincidían los intereses de los sectores medios de Taxco-Sultepec con los de Cuernavaca y, probablemente, de otras zonas novohispanas. El mismo comandante realista Félix María Calleja escribía desde Zacatecas al virrey el 20 de enero de 1811:

Voy a hablar a V\{uestra\} $\mathrm{E}\{x$ celencia\} castellanamente, con toda la franqueza de mi carácter. Este vasto reino pesa de-

\footnotetext{
${ }^{33}$ Aunque M. Ángel Michaus era adversario político de Yermo, es de interés su participación en la guerra, armando a los operarios de sus haciendas, y también su avidez por tierras en plena guerra, al expresar su exigencia "que se le satisfagan, si no en reales, en tierras realengas, los daños que han sentido sus haciendas de Buenavista y Santa Inés durante el Sitio de Cuautla", en AGN, Indiferente de Guerra, v. 401a, s. f. (1812).
} 


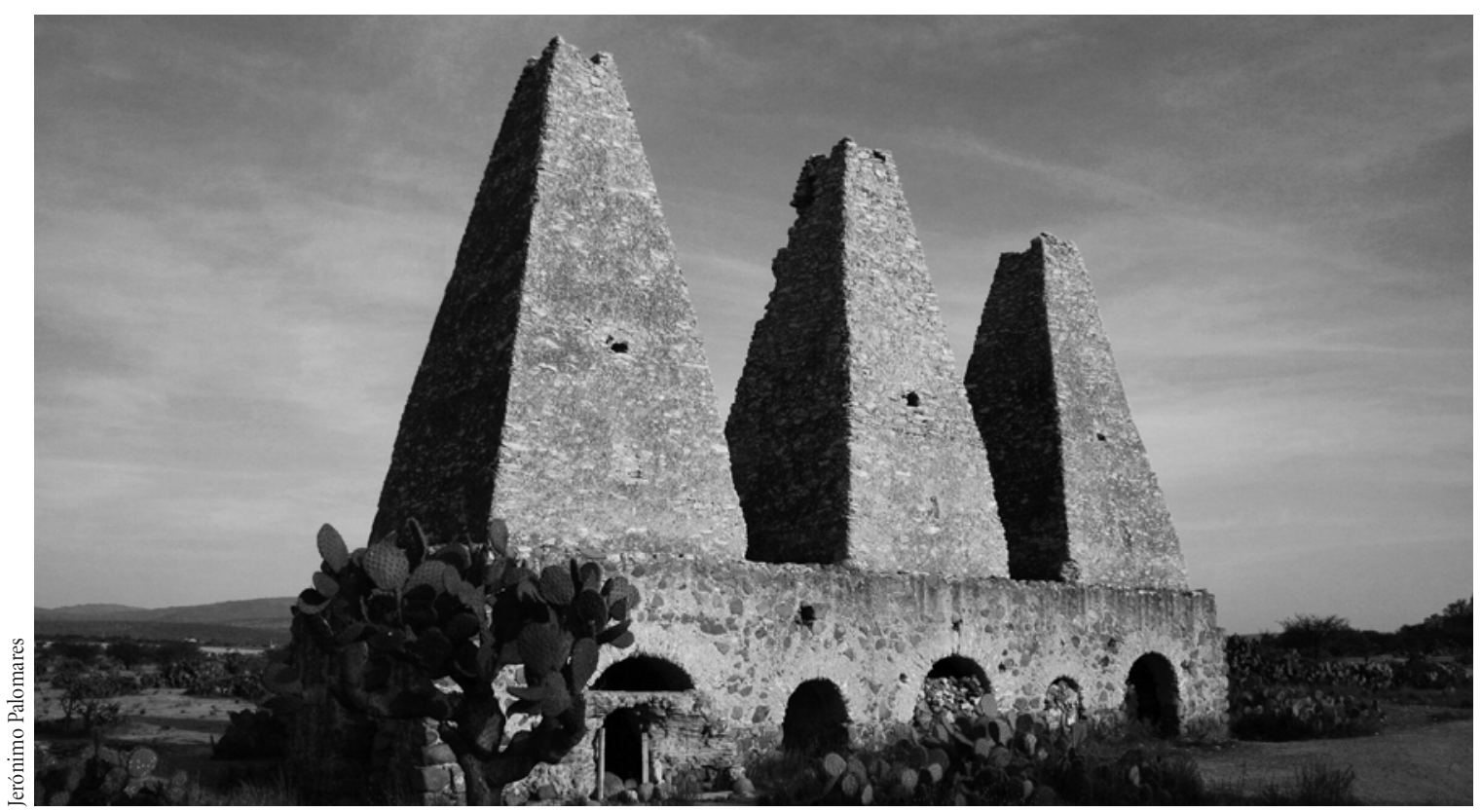

Hornos de fundición, Mineral de Pozos, Guanajuato, 2008.

masiado sobre una metrópoli cuya subsistencia vacila: sus naturales y aun los mismos europeos están convencidos de las ventajas que les resultarían de un gobierno independiente, y si la insurrección absurda de Hidalgo se hubiera apoyado sobre esta base, me parece, según observo, que hubiera sufrido muy poca oposición. Nadie ignora que la falta de numerario la ocasiona la península; que la escasez y alto precio de los efectos, es un resultado preciso de especulaciones mercantiles que pasan por muchas manos, y que los premios y recompensas que tanto se escasean en la colonia, se prodigan en la metrópoli ${ }^{34}$.

\section{LOS OPERARIOS DE HACIENDAS AZUCARERASY LOS CAMPESINOS HABLANTES DEL MEXICANO. "GALLETA" Y PAN DETRIGO VERSUS TOTOPOS DE TORTILLAS DE MAÍZ}

Si bien en las jurisdicciones de Cuernavaca y Cuautla el contraste entre pueblos y hacendados era profundo, por

\footnotetext{
${ }^{34}$ AGN, Operaciones de Guerra, v. 8, f. 142, también citado en Alamán, 1972, vol. 2: 138, y en Chávez Orozco, 1976: 43. Subrayado mío.
}

sus conflictos por los recursos, también en las empresas la situación laboral enfrentaba a los operarios con los administradores y dueños, aunque el control ejercido por los últimos podía ser férreo y el dominio absoluto: en ciertas zonas aún había esclavos (sobre todo en los emporios del oriente) y por ello las relaciones se han caracterizado como esclavistas y feudales, a la vez que específicas de una industrialización colonial ${ }^{35}$. Durante la guerra fue muy frecuente que los sirvientes siguieran a sus patrones, ya sea en batallones realistas o en grupos insurgentes, pero también se dio el caso, como en Izúcar en diciembre de 1811, de que los trabajadores de un ingenio azucarero terminaran por abandonar a sus patrones y se incorporaran al bando de los insurgentes. Muestra esa región azucarera del sur de Puebla un antagonismo entre pueblos y grandes ingenios similar al de Cuernavaca o Cuautla. Precisamente la captura de Izúcar fue de gran importancia para la lucha de José María Morelos, pues consolidó temporalmente su poderío en esa zona. Sobre el proce-

\footnotetext{
${ }^{35}$ Véase Sánchez Santiró, 2001; Mentz, 1999, así como la bibliografía de la nota 2.
} 
der de estos grupos subalternos, gañanes y empleados en las haciendas, en los álgidos primeros momentos de lucha, es difícil lanzar generalizaciones.

Se sabe que el mencionado inversionista en la región de Cuernavaca, Gabriel J. de Yermo, contaba con un grupo de "lanceros" especializados, mismo que participó en los combates al poniente de la ciudad de México en octubre de $1810^{36}$. Pero aunque los gañanes de sus haciendas de Temixco y San Gabriel (muchos exesclavos) habían mostrado lealtad hacia su patrón en las luchas de 1810 y 1811, un año más tarde, al inicio de 1812, algunos de Temixco fueron encarcelados como insurgentes. Esto se explica por la desconfianza que prevalecía en la zona. La tensión social era grande, dado que tropas rebeldes controlaban la región (entre diciembre de 1811 y finales de 1812) y se concentraban en Cuautla. A 12 operarios del ingenio de Temixco, entre ellos el indio José López (40 años), el mulato Francisco Antonio (machetero de 16 años), el mulato arriero Eustaquio Reyes (22 años), Bernardo de Carpio, mulato cortacañas (16 años) y a Nicolás Bocardo (20 años) se les acusó de haber intentado liberar a un insurgente de la cárcel. Los testimonios de los operarios permiten remontarnos a octubre de 1810 y observar de cerca cómo estos trabajadores de la empresa de Yermo tuvieron que participar en la guerra. Así relata el maestro de azúcar Juan López, a quien se le denomina en el documento "indio de la hacienda de Temixco", que había sido nombrado "cabo" en la operación militar de Las Cruces. También participaron en esa batalla los otros acusados. $\mathrm{Al}$ ser aprehendidos a inicios de 1812, la indignación de los operarios fue grande. Se les acusaba de ser cómplices de aquellos que querían liberar al insurgente Juan, alias "el Pelón", pero Juan López explicaba que, al contrario, él había apoyado a "los gachupines" en las "guerras de Las Cruces, Temixco, Taxco, Zacualpan, Iguala y últimamen-

\footnotetext{
${ }^{36}$ Decía un informe militar de octubre de 1810 de Cuajimalpa que "como los lanceros que traen los insurgentes vienen vestidos poco más o menos como los del Señor Yermo, nos ha parecido conveniente que para que se distingan, mande dicho señor Yermo una especie de banda encarnada o amarilla, de cualesquiera género ordinario". AGN, Operaciones de Guerra, vol. 402, s. n.
}

te de resguardo en San Gabriel"37. Estas declaraciones nos permiten ver la forma en la que combatió el ejército particular de Yermo con las tropas realistas en esos puntos entre diciembre de 1810 y marzo de 1811.

A pesar de haber mostrado lealtad al patrón en ocasiones anteriores, en los primeros meses de 1812 pesó el antagonismo laboral y social, que delimitaba las verdaderas fronteras de clase entre los trabajadores y los dueños de la hacienda, y por ello los propietarios no dejaron de sospechar de los 12 trabajadores. Al buscar la autoridad de Cuernavaca a los posibles cómplices en la liberación del insurgente preso, aprehendieron a estos operarios. Finalmente, fueron condenados al "servicio de la zanja", una gran obra pública de fortificación de la ciudad de México, cavando un foso alrededor de ella. El foso no llegó a concluirse pero en su excavación se ocuparon cientos de presos. De los remitidos en esa ocasión de Cuernavaca, murieron siete. Meses después del supuesto acto de sedición, en septiembre de 1812, de los que permanecían vivos, se dio libertad a tres y uno tuvo que entrar al servicio de las armas realistas ${ }^{38}$.

Hemos visto que la guerra colocó a las autoridades de los poblados del medio rural en una situación muy embrollada y comprometida. Si bien unos gobernadores de indios se sumaron a los insurgentes, otros, como el de Jiutepec, pueblo cercano a Cuernavaca, huían al igual que los peninsulares con cargos altos. Cuando los insurgentes tomaron Cuernavaca, en enero de 1812, Rosalino José, gobernador de ese pueblo, huyó "con los señores" a México; es decir, acompañó a las autoridades de Cuernavaca a la capital del reino y luego al sitio de Cuautla. Pero regresó a su pueblo. Entonces, el comandante insurgente de Cuernavaca, el cura Herrero, encarceló al gobernador realista, quien sin embargo salió con permiso de no ausentarse de la villa. Ahí lo vio el padre vicario de Jiutepec, llamado Gómez, y le dijo:

las cosas están muy malas, "porque ves que Calleja no ha podido entrarle a Morelos desde a los principios, ya no le entra... que los gachupines ya no volverán a sus casas", que

\footnotetext{
${ }^{37}$ AGN, Criminal, v. 46, e. 19.

${ }^{38}$ AGN, Criminal, v. 46, e. 19, f. 476. Sobre las relaciones de producción y de clase en estas zonas, véase Sánchez Santiró, 2001: 307-308.
} 
estaban cercados, porque Villagrán tenía 7000 hombres y estaba acampado en Chalco, cuyo camino de comunicación con México se lo tenían cortado al Señor Callejas: "que habían abierto los puertos a los franceses, quienes venían en defensa de los americanos, y que el Señor Porlier con sólo 50 hombres se había quedado, estaba para pasarse con ellos a favor de los insurgentes...", que luego el declarante oyó al padre tan apasionado por los rebeldes, sin reiterarle su súplica ni hablarle más sobre ella, se despidió y se vino para esta villa ${ }^{39}$

Lejos de permanecer ajenos a lo que sucedía en el mundo, los líderes indígenas y los religiosos pueblerinos recibían toda clase de información y de rumores esperanzadores sobre el panorama político. Eran conscientes de que les podía favorecer un régimen francés emanado de la Revolución de 1789 (que destituyó una monarquía); y también se hablaba entre los rebeldes de manera favorable sobre sus contactos con los norteamericanos, quienes les venderían armas. De tal forma que el antes nombrado "diabólico" Napoleón (enemigo de Su Majestad Católica) o los "herejes" norteamericanos habían adquirido en 1812 tintes muy positivos, incluso para algunos sectores pueblerinos tradicionales de la Nueva España. En esta revolución los dogmas, el lenguaje y los conceptos del régimen monárquico y estamental se iban resquebrajando, a la vez que en todo el reino se levantaban armas y garrotes contra los funcionarios y algunos patrones europeos.

Con independencia del papel de las autoridades políticas, los contrastes de clase en los valles del actual estado de Morelos (entre operarios y dueños, agricultores de pueblos y empresas) se agudizaban por las discordancias lingüísticas y culturales ${ }^{40}$. Los pueblos de indios de la zona, aunque muy diferenciados internamente y formados en gran medida - sobre todo en las cabeceras- por mulatos y mestizos, mantenían una noción clara de lo propio y el contraste económico y cultural de su mundo y el de habla castellana de las haciendas. Esto se manifiesta en la relevancia de la lengua náhuatl o "mexicana" para comunicarse. Aunque quizá no se tomó declaración

\footnotetext{
${ }^{39}$ AGN, Criminal, v. 44, e. 11, f. 291v. Subrayado mío.

${ }^{40}$ Véase bibliografía especializada mencionada en las notas 2 y 35 . Los contrastes podían ser menores en zonas de campesinos prósperos y haciendas menores, como en Yautepec. Véase Martin, 1885.
}

a los indígenas monolingües aprehendidos, y no tenemos muchas evidencias documentales de ellos y de su participación en la lucha, sabemos que ocho pueblos indígenas de Jojutla pidieron en enero de 1812 a Nicolás Bravo, comandante rebelde de su zona, que quitara a Miguel de Figueroa, encargado del distrito, y que en su lugar pusiera a Juan de Oliván, residente y nativo de Jojutla, pues decían que "entendía el idioma mexicano", asunto esencial para las comunicaciones con los pueblos. Según los indios, Figueroa era altivo y desdeñoso con ellos ${ }^{41}$. La importancia de la población indígena de esta zona para los insurgentes se advierte todavía en 1813, en el caso del regidor de Jojutla Juan Antonio Tlascoapan — probablemente de linaje de antiguos dirigentes de lengua "mexicana" de la zona-, quien permitió que en su casa se reunieran Vicente Guerrero y Nicolás Bravo en noviembre de ese año (o tal vez antes), preparando las conferencias sobre la instalación del primer congreso nacional (López, 1994:13). Juan Antonio Tlascoapan fue fusilado en Tlaquiltenango el día 6 de noviembre por ser partidario de la insurrección y por haber alojado a los jefes insurgentes.

Otro ejemplo de los contrastes en la zona de estudio entre el mundo castellano y el indígena, entre las tropas del rey y los rebeldes, son las armas y los alimentos de ambos bandos en esos años. Aunque sin duda esto no puede generalizarse, si observamos los informes procedentes del sitio de Cuautla, entre los primeros predominan las espadas y las armas de fuego, sobre todo la artillería. La comida se basaba en galleta, o sea, la dieta estaba basada en pan de trigo y carne. En cambio, con los insurgentes se encuentran grandes cantidades de flechas y hondas como armas principales, y totopos "como los usan los arrieros", o sea una alimentación basada en tortillas de maíz ${ }^{42}$.

Finalmente, cabe mencionar lo peligroso y aterrador que era para la población rural la invasión de sus regiones por parte de las tropas rebeldes, que exigían apoyo y

\footnotetext{
${ }^{41}$ Este incidente lo reporta Hamnett, 1990: 173, basado en una carta de Nicolás Bravo al coronel Vicente Bravo, del 26 de enero de 1812.

42 Obviamente los rebeldes también contaban con armas como los realistas, pero resaltan las sencillas del hombre de campo. Véase informes de marzo de 1812 sobre el consumo del ejército: galleta o pan sal, manteca, arroz, frijol y carne de res en Chávez Orozco, 1976: 74,
} 
amenazaban con matar a quienes no obedecían. Ni los líderes ni los pobladores comunes y corrientes sabían si gritar “ $¡ V i v a$ el rey!” o “ ¡Viva la Virgen de Guadalupe!”; si “¡Viva España!” o “ ¡Viva América!” Un artesano velero, aprehendido por las tropas realistas en Jojutla, decía que era falso que hubiese estado en la batalla de Temixco, que:

sólo lo aprehendieron porque le dieron la voz de quién vive, y se turbó en responder, pensando que si respondía "España" podían matarlo los insurgentes, y si respondía "Nuestra Señora de Guadalupe", lo mataban los de acá, y pues, no respondió nada ${ }^{43}$.

Los cuadros 1 y 2 muestran una gran heterogeneidad en la composición de los grupos rebeldes de 1810 a 1812. Era alto el porcentaje de indios y el de españoles ${ }^{44}$. En este caso, la muestra utilizada se tomó al azar, pues se trata de un total de 172 reos que fueron aprehendidos en la zona de estudio y que rindieron su declaración en Cuernavaca o en la ciudad de México. El predominio de indios, 51\% del total, seguido de españoles, 26\%; mestizos, 17\%; mulos cálculos basados en estadísticas sumamente amplias de Eric van Young. Sin embargo, las designaciones "españoles", "indios", "mestizos" y "castas" en realidad reflejan una visión estamental, colonial, administrativa y, sobre todo, fiscal. Recuérdese que, para la Real Hacienda del reino novohispano, el rubro de la contribución del tributo que pagaban los "indios" era fundamental y ocupaba el tercer lugar después de los impuestos sobre la plata y el comercio (exceptuando "estancos"). Además, la "calidad" de las personas, como se expresa en el lenguaje de

y en AGN, Operaciones de Guerra, v. 200, f.111, comentarios sobre totopos, tortillas de maíz, tomates encontrados después de la batalla de Moyotepec. Se mencionan unos 1500 infantes con alguna fusilería e indios con hondas y flechas.

${ }^{43}$ Pablo Ruiz, velero de Sultepec, aprehendido en Jojutla. AGN, Criminal, v. 48 , e. 11. f. 210-212.

${ }^{44} \mathrm{Al}$ respecto es fundamental la obra de Van Young, 2006, capítulo 2, pues ofrece estadísticas muy completas. La muestra presentada acá solamente se refiere a una pequeña parte de los combatientes que se acercaron desde el Bajío a la zona de estudio o que fueron aprehendidos en ella.

${ }^{45}$ Para su historia como insurgente véase cuadro 2, núm. 55. Al parecer estaba más bien interesado en la riqueza de las tiendas y haciendas que se saqueaban, que en política.

esa sociedad estamental, con frecuencia no proporciona mayor información social, ya que "español" podía ser un joven recién llegado de la Península Ibérica que trabajaba con un tío muy acaudalado o podía ser un artesano pobre - como los de los cuadros 1 y 2-, cuyos ancestros radicaban desde hacía siglos en la Nueva España. Por tanto, la designación no debe confundirse con la actual visión de "español" como ciudadano del Estado nacional español. En el lenguaje de la época, el movimiento insurgente tuvo un gran componente de "españoles" de sectores sociales medios y bajos (profesionistas, rancheros, artesanos, labradores), lo que no significa que estuvieran relacionados con lo que después fue el Estado nacional de España, sino que así se designaban en la sociedad estamental a la que pertenecían. En contraste, ser "indio" significaba, ante todo, tener que pagar un discriminatorio y oneroso impuesto, el tributo.

En cuanto a sus oficios, eran labradores, 22\%; operarios de campo o gañanes, 19\%; arrieros, 7\%, seguidos de varios artesanos, como tejedores, sastres o veleros, entre muchos oficios más. Un $4 \%$ del total eran operarios de minas o haciendas de beneficio, lo que se explica por las características socioeconómicas de la zona que estudiamos. Aunque la muestra es aleatoria y no puede ser numéricamente representativa, lo que merece destacarse es el carácter rural y subalterno de estos reos y del movimiento en esta zona, así como el peso de los que llevaban para combatir solamente herramientas de trabajo, garrotes, arcos, flechas y hondas. En los primeros días de combate, estos grupos sin duda tuvieron una sensación de éxito, ante repiques de campanas, comidas con los gobernadores de los pueblos, exhortaciones de curas a favor de la causa insurgente y participación en el botín — del que obtenían zapatos, trozos de telas, azúcar, etc.- - Algunos curas les regalaban estampas de la Virgen y los mismos dirigentes procuraron persuadirlos hábilmente de la bondad de su causa, con promesas, ritos religiosos, sermones, misas o procesiones con la imagen de la Virgen ${ }^{46}$.

\footnotetext{
${ }^{46}$ En los cuadros se mencionan curas "gachupines", o que "no salieron", al igual que entusiastas insurgentes. Véanse números 56 y 74. Tanto insurgentes como realistas dejaron "correr su verba con las más extravagantes declaraciones". Como precisa Alamán, "la religión servía así de instrumento a uno y a otro partido, y el pueblo no sabía a quién
} 
Diferentes relatos confirman que los insurgentes se habían puesto en las presillas de las charreteras unos cordones de plata con borlas y que llevaban en el sombrero la estampa de la Virgen de Guadalupe ${ }^{47}$. Pero hay que insistir en que se trató de una revolución en la que los pobres probablemente luchaban, sobre todo, por dejar de ser pobres (adquiriendo dinero y parte en el botín), por eliminar injusticias como el pago del tributo (es decir, "ya no ser indios"), por obtener tierras, por obediencia a un patrón o autoridad o, simplemente, por temor a represalias violentas.

\section{A MANERA DE CONCLUSIONES}

Este ensayo sostiene la tesis de que los primeros dos años de guerra civil tuvieron consecuencias trascendentes que, en cierta manera, marcaron el devenir de la historia social mexicana. De las breves escenas trazadas resulta evidente cómo participaron en la lucha armada sectores sociales muy diversos. Lejos de estar ante grupos sociales con claridad política "autonomista" o con un sentimiento "nacionalista", estamos ante grupos sociales sumamente heterogéneos, decididos a luchar en común contra "gachupines" por distintas razones.

Como ha explicado muy bien Hernández Jaimes, las causas del descontento social fueron desiguales en cada región y subregión novohispana, por ejemplo, en relación con las reformas borbónicas (Hernández Jaimes, 2002: 246 y ss). Los cambios ocurridos en las últimas décadas del siglo XVIII se dieron en función de las características socioeconómicas de cada zona. En algunas, los efectos sobre los intereses de los grupos de poder locales fueron menores; en cambio, en otras la presión fiscal y las políticas económicas oficiales contribuyeron a que una parte de las élites locales optara por la insurgencia en 1810. Ése fue el caso, por ejemplo, en la zona costera de Zacatula, patria chica de los Galeana.

creer, oyendo invocar tan respetable nombre a favor de las dos causas, y se le ponía en riesgo de no creer a ninguno". Alamán, 1972, vol.II: 26.

47 Véase a este respecto Alamán, 1972, vol. II: 283 y Van Young, 2006, caps. X y XI.
Para nuestra zona de estudio resultaron evidentes los profundos sentimientos en contra de ciertos grandes latifundistas en los valles de las jurisdicciones de Cuautla y Cuernavaca; que en Taxco y la zona minera fue grande el descontento rural contra la oligarquía minera, a la vez que existían intensas rivalidades interclasistas, y que había tupidas redes sociales entre los sectores sociales intermedios (sobre todo curas) y los líderes insurgentes del Bajío. En estas comarcas ricas, cercanas a la ciudad de México y con empresas poderosas, al parecer los distintos grupos sociales proinsurgentes compartieron el odio a los funcionarios que representaban el régimen reformista borbónico (y que fueron los primeros en huir), y a los grandes comerciantes-inversionistas de la capital del reino. Ellos controlaban el numerario, se enriquecían con el intermediarismo comercial, obtenían privilegios injustos y podían sobornar a los oficiales reales. Incluso, algunos habían usurpado el poder virreinal en 1808.

Además de una guerra civil y de un movimiento de disputa por el poder en el reino entre sectores económicamente dominantes, la guerra iniciada en septiembre de 1810 también fue - al menos en nuestra zona de estudio - un conflicto revolucionario espontáneo y popular, expresión de la gran pobreza y la profunda desigualdad social. Las bases sociales del movimiento fueron muy heterogéneas. Para los líderes de clase media y alta, sin duda fue muy difícil considerar las fronteras entre "europeos" y "americanos", pues ante todo eran fronteras políticas. En tanto propietarios, estaban lejos de querer fomentar la "guerra de castas"; o sea, el conflicto racial, étnico-cultural $^{48}$.

Pero desde el punto de vista de los grupos subalternos, aquellos que lucharon con hondas, piedras, arcos y fle-

\footnotetext{
${ }^{48}$ Esto fue evidente en la zona de Acapulco, donde el contraste entre la población mulata y la élite novohispana-mexicana siempre condujo a profundos resentimientos, como explican Hernández Jaimes, 2002: 234-239 y Hamnett, 1990: 173. El término "criollo" se usaba en la época virreinal simplemente como lugareño, nativo, local o "de acá". Por eso, a mi modo de ver, debe usarse con mucho cuidado y sin proyectar al pasado "nacionalismos" o significados posteriores relacionados con los Estados nacionales del siglo XIX. Esos nuevos significados los adquirió el término en la Guerra de Independencia y en la interpretación republicana, cuando se contrastó a los americanos o "criollos" de la República Mexicana, con los "españoles" de la monarquía española.
} 


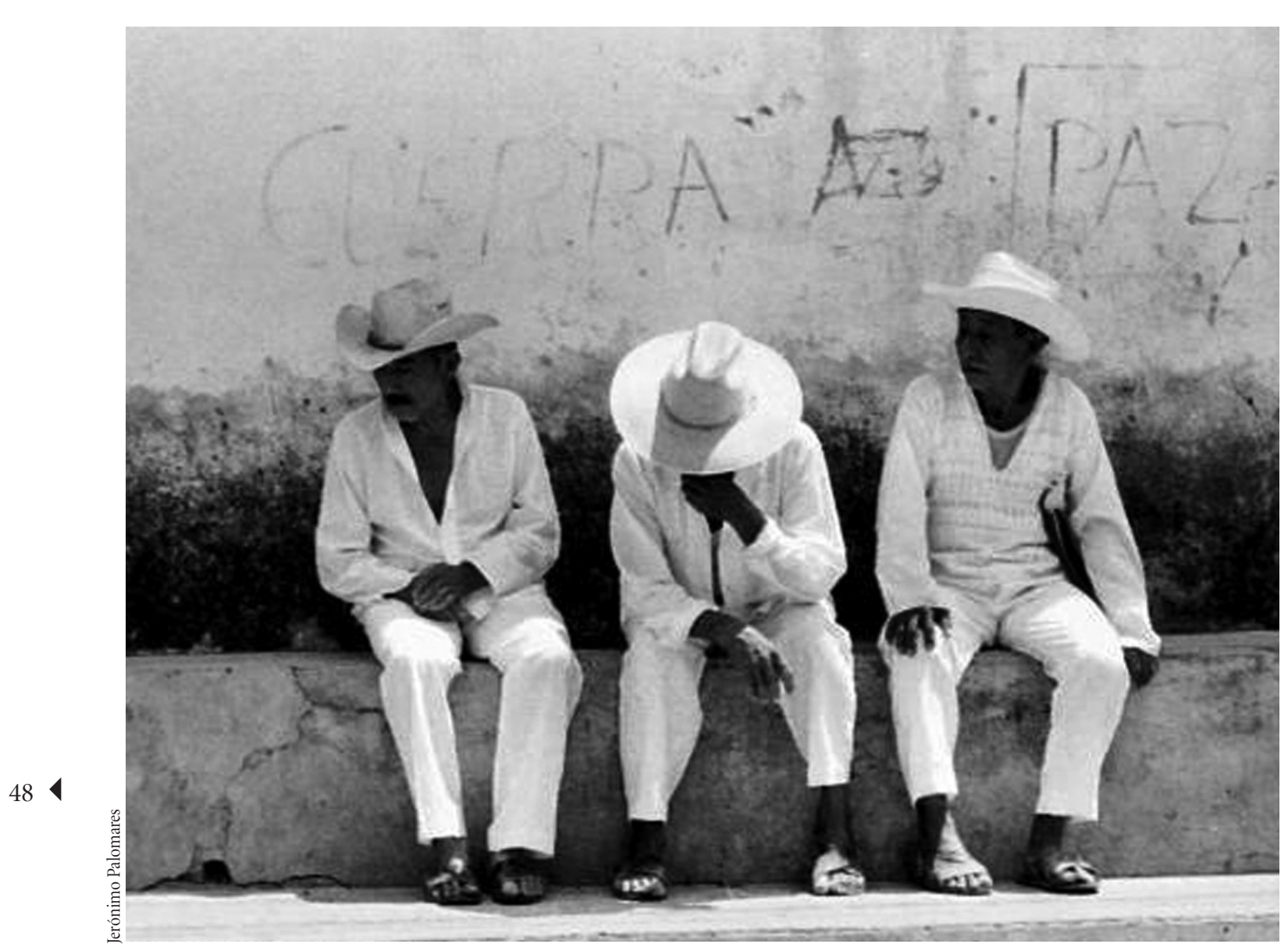

Venustiano Carranza, Chiapas, 2005.

chas, machetes y garrotes, resultaba bastante claro quiénes se incluían en el "nosotros" y quiénes eran los "otros". Ellos eran la "plebe" (como decían los que se consideraban "decentes"), eran los "plebeyos", como decía en noviembre de 1810 el autor del Periquillo Sarniento, al referirse a aquellos que "no eran de confiar" en Taxco. Sus reivindicaciones estaban motivadas sobre todo por agravios locales y por la pobreza, aunque en términos militares seguían a líderes regionales de clases acomodadas, a sacerdotes y propietarios de haciendas y ranchos. Muchos agravios no se resolvieron pronto, pero el hecho de que los sectores populares tomaran las armas es significativo: la Revolución de 1810 resquebrajó un orden estamental que se había presentado durante siglos como inamovible e instituido por Dios. En esa toma de armas generalizada de los grupos subalternos en todo el reino consiste el acto revolucionario. Ocurría algo equivalente a las guerras campesinas en época de Lutero en Europa central: se armaron los pobres contra los señores.

Así, podemos concluir subrayando el peso que tuvieron los sectores de agricultores, trabajadores y artesanos en la guerra. Muchos sentían, por primera vez en su vida, los efectos de su actuación colectiva y armada contra la clase dominante. Aunque no fueron pocos los que estuvieron involucrados sólo unas semanas en la rebelión y luego regresaron a sus labores cotidianas, en general la vida de muchos participantes cambió profundamente. En los años reseñados brevemente, las vivencias de mu- 
chos combatientes fueron atroces. Vieron a sus parientes y compañeros morir, sus casas arder, a sus esposas "tusadas"; a la vez, presenciaron el fusilamiento de algunos de los hombres más ricos e influyentes del reino, que morían en combate señores y condes; también fueron testigos de cómo sus poblados eran destruidos por el saqueo y el fuego, como ocurrió en Zitácuaro, Tenango, Cuautla e Izúcar. En el caso del pueblo de Huajintlan, al sur de Cuernavaca en el camino a Taxco, por ejemplo, presenciaron cómo sus mujeres y niños se ahogaban en el río Amacuzac. Cientos murieron presos, hacinados en las cárceles o realizando trabajos forzados; otros terminaron en el destierro en La Habana o trabajando en la zanja que se cavaba alrededor de la ciudad de México; otros más se escondieron en parajes y montañas que antes no conocían, lejos de su tierra natal, o fueron obligados a combatir en el bando contrario. Pero a todos ellos se deben en buena medida las transformaciones políticas y los cambios que provocaron al tomar sus palos, machetes, hondas y piedras, pues con eso socavaron, de manera generalizada en muchas regiones de la Nueva España, el principio de autoridad.

Si éstos fueron años de ruptura por esos trabajadores armados por primera vez en casi todo el reino, también lo fueron por la alianza con las oligarquías regionales, deseosas de la autonomía de una metrópoli que había caído en manos de los franceses, y que había sido indiferente a los intereses de sus vasallos en la Nueva España. Las oligarquías regionales (los De la Vega y Benítez de Taxco, los Romero en Zacualpan, los Estrada de Tepecoacuilco, o los Bravo, Galeana, Guerrero o Álvarez, por ejemplo) sentían que tenían el derecho de incidir en el rumbo político que debía tomar la "nación", término di- fundido por José María Morelos y sus capitanes en la guerra, y acuñado en el sentido liberal del nuevo Estado nacional. Lo ocurrido en Cuernavaca en octubre y noviembre de 1810 confirma esta indignación "americana" ante los "gachupines que ponían sus virreyes".

Sin embargo, el descontento rural en la zona azucarera o minera rebasaba las ilusiones de los grupos medios urbanos. Ese descontento de los trabajadores del campo era profundo, añejo, y no se resolvería fácilmente. El júbilo con que se recibió la promesa del reparto de aguas y tierras es reflejo de una larga historia de profunda desigualdad social en la zona y de conflictos agrarios, especialmente agudos desde el siglo XVIII. Al considerar el peso de los reclamos ante agravios regionales específicos, observamos que tiene razón el historiador Brian Hamnett al enfatizar las continuidades locales muy duraderas en la historia de México (Hamnett, 1990: 123). Según la propuesta de este estudioso, en lugar de interpretar las luchas independentistas como el inicio de un nuevo periodo, éstas deben unirse al periodo del siglo XVIII. Las evidencias aquí mostradas, en cuanto al motivo de muchos participantes populares en la guerra de las zonas mineras y azucareras al sur de la capital, señalan, efectivamente, en esa dirección. Pero incluso también hacia el futuro, si por lo que toca a los valles de haciendas azucareras pensamos en la guerra que estalló con la revolución zapatista en 1910. En ese sentido, en las escenas aquí reseñadas aflora la lacerante desigualdad social por el peso de la pobreza, el conflicto agrario entre pueblos y haciendas y, en especial, la indignación ante los grandes inversionistas de la ciudad de México. Todo ello apunta claramente tanto hacia el pasado colonial como hacia la Revolución de 1910. 
Cuadro 1. Algunos aprehendidos acusados de ser insurgentes en zonas mineras (continúa en la sig. página) NOMBRE y edad del reo \| Oficio, "calidad"y origen \| Declaración (se destacan en negritas cuestiones de interés para este artículo)

José Lucio Bustos, 28 años || Operario de minas español de Tzicapan || 1. Lo aprehendieron en Zacualpan, sin haber estado en la guerra. Por ser de parte de acá, lo aprehendieron los insurgentes, lo pusieron en la cárcel con dos pares de grillos. Después de la guerra lo echó un insurgente, que fue cuando lo aprehendieron las tropas del rey.

José INÉs SOTELO, 25 años || Operario de minas, mestizo de Zacualpan || 2. Estando en su casa lo perseguían continuamente los insurgentes... bajando a deshoras de la noche a sorprenderlos, tuvo que emboscarse en el monte, pero apretándole el hambre, tuvo que solicitar bastimentos y entonces lo aprehendieron las tropas del rey.

JACOBO, 30 años || Gañán, indio de la hacienda de Acayacuala || 3. Que como su amo es don Francisco Benítez, y ser éste capitán de insurgentes, se llevó a todos sus sirvientes con dirección a Tepecoacuilco para la guerra que ahí hubo. Que sólo un día acompañó a los insurgentes, no le dieron nada, ni aún ni comió.

José Bayna || Trabajador en hacienda de beneficio, castizo en el rancho San Pedro, Taxco \| 4. Trabaja en la Hacienda de Pregones. Lo aprehendieron entre los pueblos de San Andrés e Iguala por andar con los de la compañía de Francisco Hernández. Que tres veces éste había ordenado a los de la hacienda a unirse y la cuarta fueron unos comisionados y a fuerza los llevaron a Tetipaque, a Cuitlapan y de ahí a Iguala. Que se escapó hacia Coatepec, pero otros guardas de los insurgentes lo atraparon. Que no le dieron reales, sólo de cenar.

Francisco Xavier, "como de” 30 años || Operario de minas, indio de Taxco || 5. Yendo a comprar maíz a la plaza lo aprehendieron el domingo, día de la guerra, sin llevar arma alguna, ni haberse metido en dicha guerra.

JuAn SÁncheZ, "más de” 50 años \| Operario de minas, mestizo de Temascaltepec $\|$ 6. Fue criado en Tecualoya. Lo aprehendieron en Zacualpan, no sabe por qué. Llegó ahí mismo el día de la batalla con los insurgentes, pero después de ella y andando en la plaza en solicitud de una mula que se le había perdido, supo que la habían cargado para el tianguis del domingo, entonces llegaron los soldados de San Gabriel y lo aprehendieron, pero nunca anduvo con los insurgentes, ni los vio, porque cuando llegó, ya no estaban allí.

José Manuel Carranza, 34 años || Barbero, español de Puebla || 7. Fue a Sultepec a vender un poco de queso, pasó a cobrar unos reales a Mariano Pereyra por encargo de su hermano a Zacualpa. Estaba comiendo en la orilla del pueblo cuando oyó el ruido de la batalla y salió en solicitud de su mula que había dejado amarrada en un palo ensillada y enfrenada y con su manga sobre la silla. Pero no halló dicha mula y antes por el contrario, encontrándolo un güero y otros lanceros de Taxco que llaman de los Pregones, teniéndolo por insurgente lo aprehendieron y llevaron a la cárcel, donde hizo varias diligencias para probar lo que lleva referido como el dinero del queso y la carta de Pereyra, pero nada le valió y lo llevaron a la cárcel de Taxco y de ahí a ésta.

José Guadalupe, 50 años || Carbonero, indio de Nochtepec || 8. En Zacualpan, yendo a vender su carbón el domingo, no vio la guerra, pues estaba distante cosa de una legua.

Miguel Jerónimo, "como de" 30 años || Carbonero, indio de Chontalcoatlan || 9. Estando en su casa cayeron de noche los insurgentes y llevaron al declarante y a otros compañeros forzados al campamento. Que en prueba tiene en el brazo las señales de la fuerza con que lo amarraron para llevarlo. Que así amarrado lo tuvieron en dicho campamento dos días, hasta el domingo de la guerra de Taxco, que lo llevaron así. Y ya estando, lo desataron para que peleara pero sin darle arma alguna, sino advirtiéndole que lo hiciera con las manos o con piedras, pero el declarante no lo hizo, ni alzó piedra alguna, antes se huyó luego que pudo. Y se fue a su casa de donde fue a sacarlo su capitán del pueblo, que llaman Almonte y lo llevó preso a Taxco, de donde lo remitieron aquí. Que los dos días que estuvo con los insurgentes no le dieron ni un real, ni tampoco qué comer y se mantuvo con el poco itacate que llevó de su casa y le dio su mujer. Que no sabe cómo se llama el capitán o principal. 
Cuadro 1. Algunos aprehendidos acusados de ser insurgentes en zonas mineras (continuación)

NOMBRE y edad del reo \| Oficio, "calidad"y origen \| Declaración (se destacan en negritas cuestiones de interés para este artículo)

José Antonio Máximo, “mayor” de 20 años || Carbonero, indio de Taxco || 10. Que no ha andado con los insurgentes y no sabe por qué lo aprehendieron, porque aunque es de Taxco, está viviendo en el monte donde hace carbón y sólo bajaba a entregarlo en las fundiciones, particularmente la de Cantarranas, sin haber entrado a Taxco hace más de un mes. Que estaba en el dicho monte cuando los de Taxco fueron a aprehenderlo.

José Francisco Dionisio, "como de" 20 años \| Carbonero, indio de la jurisdicción de Taxco \| 11. Que estaba en el monte haciendo carbón y que el sábado que pasaron por el camino, que está inmediato, los insurgentes para el real de Taxco, bajó también el que declara con ánimo de irse a presentar al gobierno, pero no lo logró, porque antes de llegar lo vieron los alguaciles, lo aprehendieron y llevaron a la cárcel, de donde lo trajeron a aquí, sin haber dado motivo alguno.

José Mariano OrTiz, 46 años || Carbonero, mestizo de Taxco || 12. Que vive en las orillas de Taxco, lugar o sitio de Cantería, donde estaba el campamento de las tropas del rey, con las que se juntó en el trozo de Nueva España, y le dieron una lanza para que ayudara el día de la batalla. Vio poco de la batalla porque huyeron los insurgentes. Que después se quedó en su misma casa, asistiendo a su familia y allí estaba el viernes, después de la batalla, cuando mandó por él don José Zárate y don Manuel Gómez, que son capitanes del rey en Taxco, lo mandaron poner en la cárcel y de ella lo enviaron aquí.

Juan Antonio Vera, 80 años || castizo de Taxco || 13. Que insurgentes bajo Francisco Hernández y M. de la Vega, que ambos son mineros, lo obligaron pena de la vida unírseles... los acompañó hasta Huizuco, no hubo, ni vio guerra de balazos... que sólo vio un robo de cargas de ropa que serían como 40 y una carga de dinero que sacaron de Tepecoacuilco... que ahí lo aprehendieron cuando hubo guerra... Que el cura de Iguala se huyó, que sólo el gobernador y el teniente cuyos nombres no sabe, los salieron a recibir y les replicaron... que un clérigo de Valladolid, apellidado Talavera, decía que creyeran todos que traían a Nuestra señora de Guadalupe y al rey Fernando $7^{\circ}$ en una vidriera, que estaban en Querétaro, y no creyeran en las leyes de los gachupines, porque iban matando a mujeres y criaturas y por eso estuvo el declarante con ellos dos meses.

Gutiérrez, s. a. || Sillero, español de Axuchitlan || 14. Se unió al capitán Hernández, llevaba la bandera con una cruz encarnada al frente. Tomó diez vacas. Menciona al gobernador de indios de Axuchitlan, que encerró a 300 indios para que entraran como insurgentes.

José Mariano Rojas, “como de” 20 años || Carpintero, indio de la jurisdicción de Taxco \|15. Que no ha andado con los insurgentes ni los ha visto. Fue cuando pasaron por Texcaltitlan solamente que los vio, pero que cuando éstos entraron a Taxco, todavía el declarante estaba en su tierra y después fue cuando vino al dicho Taxco a partir texamanil con un primo suyo, y en este trabajo estaban en el monte, cuando fueron los soldados del rey y los aprehendieron.

Miguel Soriano, 18 años || Peón de hacienda, indio de Taxco \| 16. Lo aprehendieron bañándose en el río de Tecuanapan al cuarto día de la guerra de Zacualpan, que no la vio por estar en su casa.

José CRISPín, “como de” 20 años || Operario de campo, indio de Taxco || 17. En Ixtlahuacan lo aprehendieron al sexto día de la guerra de Zacualpan, no vio la guerra, quiere saber el motivo por el que lo han traído.

Julián Antonio, 26 años || Labrador, indio de Taxco || 18. Que don Ildefonso Mengal de la Hacienda de San Gabriel lo despachó con una carta para su esposa que estaba en el mismo San Gabriel y dicho Mengal en Taxco. Mas en el camino lo aprehendieron los insurgentes, le rompieron la cabeza y le rompieron la carta, llevándolo preso a su campamento de ellos, metiéndolo amarrado hasta las cuatro de la tarde que lo remitieron con seis hombres a otro trozo de gente distante; pero habiendo logrado las tropas dispersar el montón, lo aprehendieron. Pero que él en nada se metió. Que los cabecillas fueron don Dionisio Toledo y don Mariano Toledo, que únicamente traían dos cañones. 
Cuadro 1. Algunos aprehendidos acusados de ser insurgentes en zonas mineras (continuación)

NOMBRE y edad del reo \| Oficio, “calidad” y origen || Declaración (se destacan en negritas cuestiones de interés para este artículo)

José ANTONio CRUZ, 28 años || Arriero, mestizo de Cocula || 19. Se vino de Cocula para Taxco a vender una carguita de maíz y habiéndola vendido y estando comiendo, lo aprehendieron sin motivo, que no se ha metido con los insurgentes.

José DE LOS SANTOS, 25 años || Operario del campo de la hacienda de Coixtlahuaca || 20. Que no anduvo con los insurgentes ni los ha visto. Que una vez que pasaron por la hacienda por el mes de Nochebuena, estaba el declarante pizcando en una barranca. Que el domingo de la guerra de Zacualpan estaba el declarante en su casa en la hacienda, y estando bañándose en el río por la hacienda, llegó Juan Luis que dicen que es capitán en Taxco, y lo aprehendió sin motivo.

Santos Mateo, 60 años || Operario del campo Cuatepeque, jurisdicción de Zacualpan || 21. Que el domingo de la guerra de Zacualpan, antes de ella, estaba en la plaza vendiendo una fanega de maíz, y vinieron unos soldados lanceros ylo aprehendieron, que él nunca ha andado con los insurgentes.

JUAN PEDRo, "mayor de" 25 años || Arriero, indio de Mamatla || 22. Que el domingo de la guerra de Zacualpan había ido su madre a la plaza y yendo él a encontrarla, lo aprehendieron los soldados del rey. Nunca ha visto a los insurgentes.

PASCUAL SÁNCHEZ, “mayor de” 25 años || Labrador, indio de Mamatla || 23. Que había acudido a la plaza a vender plátanos y cuando volvía a las tres de la tarde, con recaudo de cocina, lo encontraron con su muchacho las tropas del rey y le quitaron su caballito, su machito y el recaudo.

NAZARIO José, 40 años || Labrador, indio de Iguala || 24. Que nunca vio a los insurgentes. Que el miércoles después de la guerra, estando en su casa, llegaron unos lanceros de don José Carmona y lo llevaron a la cárcel. Que no encontraron arma, ni resistió.

José VALENTín, 40 años || Labrador, indio de Iguala || 25. En su casa en Iguala lo aprehendieron. Estaba dándole de comer a sus animalitos. Que cuando la guerra, estaba también en su misma casa, como lo testificaría el gobernador de su pueblo.

José Severino Arellano s. a. || Arriero, indio de Tepantla, jurisdicción de Tepecuacuilco \| 26. Que viniendo el jueves después de la batalla de Taxco del río de Agueguepa para Iguala, con dos pares de zapatos que había ido a comprar, lo encontraron unos lanceros del comandante don José Armona [¿Carmona?] y lo amarraron y llevaron a la cárcel. Que el día de la guerra de Taxco, estaba en su tierra acarreando maíz para Tepecoacuilco [hubo por tanto una batalla en la plaza y otra en el río].

José HernándeZ, “como de” 30 años || Operario del campo, indio de Iguala || 27. Que no sabe el motivo de su prisión, pues estaba recogiendo su maíz de sus milpas y mudándolo a su casa hace más de un mes, y el viernes, después de haber pasado la batalla, estaba en su casa almorzando, cuando llegó la república [las autoridades del pueblo] prendida de su gobernador y sin saber por qué, lo mandaron llevar a la cárcel, de la que lo pasaron a la de Taxco y de ésa a ésta.

Josefino DE JEsús, 29 años \| Albañil, indio de Tenancingo || 28. En Zacualpan, las tropas del rey [lo aprehendieron], estando en su casa, su hermano se estaba muriendo. La guerra duró una hora, pero no la vio. Que uno de los cabecillas en Zacualpan era un tal Carmona, que decían era de Sultepec. Otro era Romero. Que un don Lucas tenía correspondencia con insurgentes en Zacualpan, que también el gobernador de Zacualpilla. Que el cura no se metió en cosa alguna.

ISIDORO ViCENTE, “más de” 50 años || Operario del campo, indio de Tenango del Valle || 29. En la plaza de Zacualpan, cuando iba a aviarse de su recaudo, lo aprehendieron. Él estaba en su casa, no vio la guerra. Sólo oyó mentar a un tal Toledo por principal de la guerra. 


\section{Cuadro 1. Algunos aprehendidos acusados de ser insurgentes en zonas mineras (continuación)}

NOMBRE y edad del reo \| Oficio, “calidad”y origen || Declaración (se destacan en negritas cuestiones de interés para este artículo)

José Ciriaco Martínez, 40 años || Curtidor, indio de Coatepec, jurisdicción Ixtapa \| 30. En Sultepec los insurgentes lo cogieron por fuerza para que anduviera con ellos, como lo hizo, dándole por ello 4 reales diarios. Que habiendo parado a Zacualpan a comprar un corte de jerguetilla, lo vieron los insurgentes de quienes antes se había ausentado, y le precisaron a volverse a servirles, y como se resistió lo pusieron preso. Al retirarse de la guerra de Zacualpan para Tecomatepec, lo aprehendieron las tropas del rey.

Hermenegildo Antonio, "como de" 40 años || Operario del campo, indio de Ostotitlan || 31. En Zacualpan, estando vendiendo chile [lo aprehendieron]. Cuando fue la guerra estaba en la plaza.

LUCAS BernaBé, "como de" 30 años || Operario del campo, indio de Alahuistlan || 32. En Zacualpan [lo aprehendieron] estando vendiendo maíz. Estaba en la plaza a la hora de la guerra. Ni en ella se metió, ni la vio.

OnOFRe ANTONio, 20 años || Labrador, indio de Mamatla || 33. Lo aprehendieron en el camino a Taxco el sábado, un día antes de la guerra, sin saber por qué delito.

José Manuel, “como de” 40 años || Gañán frutero, indio de Mamatla || 34. Viniendo a placear con un caballito con cuatro canastos de chirimoyas para vender a Taxco, el sábado lo encontraron los demonios de los insurgentes y lo amarraron. A la hora de la guerra se desató él mismo y se fue a esconder a una barranca, donde lo prendieron las tropas del rey.

Manuel Miguel, 30 años || Frutero, indio de Mamatla || 35. Estando vendiendo maíz lo aprehendieron las tropas del rey sin dar motivo, le quitaron 1 peso que traía en la bolsa, un costalito de sal y un cotón.

Anastasio de la Cruz, “como de” 15 años || Milpero, indio de Mamatla || 36. Yendo para su casa, lo aprehendieron las tropas del rey y le quitaron un caballo y un machito, no sabe qué es guerra.

José Manuel, 25 años || Operario del campo, indio de Coatepec \|| 37. Lo aprehendieron el jueves antes de la guerra en el camino de Zacualpan, donde iba a traer un queso, y le quitaron un macho, su queso y un manojo de cebollas. Ni aun siquiera conoció a los insurgentes.

Tiburcio Basilio, 40 años || Labrador, mestizo del rancho de Metlalpa || 38. Estando pescando en el río de Agueguepa junto con otros, los aprehendió don Juan Luis de Iguala, creyendo ser sus compañeros insurgentes, por traer una lanza, lo que no es cierto. Ni los ha visto a los insurgentes.

José Antonio, 25 años || Labrador, indio de Tomatal, jurisdicción de Tepecuacuilco || 39. Viniendo del río de Agueguepa a donde fue a ver a un hermano suyo, lo encontró en el camino Juan Luis, que venía con una punta de lanceros, y sin más averiguación, lo aprehendieron. Que cuando la guerra, estaba en su casa, desgranando maíz, que ni conoce a los insurgentes ni los ha tratado.

José LuCiAno, 25 años || Labrador, mestizo de Acayahualco || 40. Que viniendo de su pueblo para Iguala a comprar maíz, lo aprehendieron, que cuando la guerra estaba en su casa sumergido en ella de temor.

José Mauricio, 30 años || Labrador, indio de La Tenería, jurisidicción de Taxco || 41. Saliendo de La Tenería, lo aprehendieron y se lo llevaron los insurgentes a Taxco, pero logró fugarse y ocultarse en una barranca, donde lo encontraron unos soldados con lanzas y lo condujeron preso, remitiéndolo en cuerda. Cuando la guerra, él estaba en una barranca y sólo oyó los truenos del cañón. 
Cuadro 1. Algunos aprehendidos acusados de ser insurgentes en zonas mineras (continuación)

NOMBRE y edad del reo \| Oficio, "calidad”y origen || Declaración (se destacan en negritas cuestiones de interés para este artículo)

José Francisco Mendes, “como de” 29 años \|| Arriero, mestizo de Acayahualco || 42. Que viniendo de Tepecoacuilco para Iguala con su hermano, lo encontraron los lanceros de don José Carmona, lo amarraron y condujeron preso a Iguala. Iba a buscar una yegua en el llano. Que cuando fue la guerra él estaba en San Gabriel donde trabajaba, por lo que es inocente.

José N. Salgado, “como de” 35 años || Arriero, indio de Zumpango del Río || 43. Que los insurgentes fueron a su casa y lo amarraron y llevaron a Tepecoacuilco a la guerra, dándole para ella un garrote.

R. Trujillo, 50 años || Matador de cerdos, mestizo de Valladolid, vecino de Talchapa || 44. Lo sacaron de Talchapa como lo hicieron con otros cincuenta o más y llegando al real de Tetepatitlan se desertó... fue entregado luego por el teniente de Justicia de Axuchitlan, don Miguel Quezada, y anduvo tres días en el castillo de Iguala, y en la guerra. Que asistió el declarante sirviendo un cañón, en llevar las municiones para que lo cargasen con plomo de herraduras y clavos, con pólvora, como libra y media, que dicho cañón sólo dos descargas hizo, pero no mató a ninguno... que era de cinco cuartas, según hace memoria... que las balas estaban en el cerro de Iguala donde tenían formado el castillo y se hallaba la Santísima Virgen de Guadalupe, que en el castillo tendrían unas siete cargas de pólvora... los [capitanes] eran don Francisco Hernández y don Manuel de la Vega, que no los conoce.

José Rafael Popota, 30 años || Botero, español de Xochimilco \| 45. Que siendo patriota de la Compañía de don José Carmona, tuvo una riña en Taxco con otro soldado, sobre de quién era un trabuco, por lo que se armó disputa y le dio un cañonazo, por lo que lo metieron a la cárcel. Pero que él lejos estaba de ser insurgente, pues se alistó voluntariamente para defender la Patria.

Fuente: AGN, Criminal, v. 45, e.12, f. 344-362. Reos remitidos el 21 de marzo de 1811 en calidad de insurgentes de la cárcel de Taxco o Cuernavaca a México. AGN, Criminal, v. 204, f. 263 y ss. Declaraciones de reos insurgentes procedentes de Iguala y Cuernavaca, enero 14 de 1811, núms. 3, 4, 13, 14, 43 y 44. Selección y destacados míos.

Cuadro 2. Algunos aprehendidos acusados de ser insurgentes en el Valle de Cuernavaca

NOMBRE y edad del reo \| Oficio, "calidad"y origen || Declaración (se destacan en negritas cuestiones de interés para este artículo)

José FaUSTino Flores, 45 años \| Panadero, pero se mantiene de labrador, español de Sultepec, vecino de San Mateo Tetecala \| 46. Que el domingo que hubo una guerra en Temixco, estando sentado en la puerta de su casa, como a las 9 de la mañana, llegó un hombre a caballo de pantalones azules, chaqueta listada de canícula, unos galones en el sombrero y otros en el hombro, diciéndole que era capitán del comandante, que había salido a dejar órdenes a los pueblos. Y así que le sirviera de guía, para enseñarlo los que había, que en efecto lo llevó a Jojutla, Panchimalco y Tlatenchi... que estando en Tlaquiltenango, le mandó dicho teniente al alguacil mayor fuera a juntar a los indios, y habiendo como 100 hombres, ...fueron buscar al capitán, pero no estaba en la hacienda de 30 pesos... siguieron para Xochitepec, de donde se escapó el que habla. Que el miércoles siguiente por la tarde lo mandaron llamar a su casa los gachupines de la hacienda de Chiconcoac y preguntándole si había sido guía de un capitán, les dijo que sí, y que entonces lo prendieron.

José Bonilla Figueroa, 30 años || Alguacil mayor de Tlaquiltenango, español de la ciudad de México || 47. Que el domingo 11 del corriente [noviembre 1810], lo mandó llamar el teniente del pueblo, don Ignacio Ursúa, y al ir a su mandado le salió al encuentro el tendero nombrado don Gabriel de Arce, diciéndole que lo había comisionado don Ignacio para que fuese a recibir al ejército de insurgentes, y ya don Gabriel venía con otro, y al irse para Jojutla se encontraron con uno que traía una bandera encarnada y porción de gente, y yéndose para Tlaquiltenango con la gente que se había juntado, de suerte que el de la banda encarnada le dijo al que habla, que de no darle auxilio, le volaba la tapa de los sesos, y por esto lo acompañó una tarde y logró retirarse... Que el teniente del pueblo, don Ignacio Ursúa está dudoso si se fingió enfermo o en la realidad lo estaba, por no dar auxilio a los insurgentes. Que don Gabriel por mero cumplimiento fue a hacer que los recibía, pero luego se escondió y no vio los acompañara, y que ni el cura, ni el teniente de Tlaquiltenango se metieron en cosa alguna. 


\section{Cuadro 2. Algunos aprehendidos acusados de ser insurgentes en el Valle de Cuernavaca (continuación)}

NOMBRE y edad del reo \| Oficio, "calidad"y origen || Declaración (se destacan en negritas cuestiones de interés para este artículo)

Cayetano SaAvedra, 20 años || Labrador, español de Cuernavaca || 48. Que estando en Cocoyotla, donde su padre tiene hacienda, se le presentaron los insurgentes y lo precisaron para que los acompañase, pena de vida, pidiéndole relación de los europeos. Dijo no haber ninguno, aunque sabía dónde había algunos, y llevándolo a San Francisco Tetecala, impuesto el comandante Rubalcaba de que padre tenía hacienda, le entregó en depósito cuatro tiendas, tres que saquearon y la otra que por arbitrio del declarante la libertó a su dueño que lo es don José Huerta. Igualmente le entregaron dos haciendas que fue la de Santa Cruz y la de San Miguel Cuautla, mandándolo al efecto sólo con ocho hombres, y cuando llegó Rubalcaba, le dijo que ya estaban saqueadas, arriesgándose a que lo hubiera mandado matar... como serán testigos... se ausentó el ejército... puso un estado al Exmo. Sor virrey por mano de don Francisco Gabino, que no sabe su paradero, y yéndole a dar razón al comandante que fue de acá, sin oírlo lo mandó preso y remitieron a esta cárcel... que no tuvo medio real de los insurgentes y antes se le ha perjudicado en una tienda que tiene en Malinalco... [tiene tiendas, pero no sabe escribir].

José de la CruZ, 30 años \| Gañán, indio de Tetecala \| 49. Que cuando hubo el tumulto en Temixco, digo, en San Francisco, que abrieron y robaron las tiendas sacando mantas, sólo estaba mirando el que declara, sin haber robado ningunas, ni tampoco acompañó a los que robaban.

JUAn José LeDESMA, 22 años || Labrador, español vecino de la hacienda de Barajas, Celaya || 50. Que cuando estuvo el comandante don Ignacio Rubalcaba en su pueblo, por instancias de un amigo suyo, se apuntaron en aquel ejército con el que anduvo 19 días, recibiendo 1 peso cada uno, porque era de a caballo... que en el saqueo de una hacienda que está delante de Jerécuaro sólo le dieron un pilón de azúcar, dos piloncillos de panocha y como dos libras de algodón. En el [saqueo] de Actopan tuvo un rebozo ordinario, como cuatro varas de ralladillo y un corte de cambadas. En el de la hacienda de San Gabriel de lo que tiraron sólo cogió una pieza de manta. En el de la hacienda de San Gaspar le dio el comandante una casaca o chaqueta de ralladillo, unos calzones, medias pardos de paño y una solapa de colonia. Que es la que trae puesta, porque lo demás lo vendió. Que lo prendieron al entrar a Cuernavaca, cuando mataron al comandante. No tuvo ningún cargo... al llegar a la orilla de Cuernavaca por Chipitlan, se encontraron una cuadrilla de hombres de aquella villa, que los recibieron tirándoles de balazos, y aunque se hincó don Ignacio Rubalcaba, diciéndoles a los que iban con él que no hicieran resistencia, le dispararon un trabucazo y lo mataron, casi al lado del declarante, y a éste lo prendieron en compañía de otros. Que estando preso, llegó su amo a Cuernavaca, a hablarle por la azotea de la cárcel, diciéndole que por qué no se había huido de aquéllos, aun le tiró 4 reales.

Agustín NúÑEZ, 25 años || Operario de campo, mestizo de Tetecala || 51. Que sólo un día anduvo con ellos [los insurgentes] que le dieron dos piezas de manta pintada.

CRistóbal Ceballos, 40 años || Albañil, indio de Tetecala || 52. Lo aprehendieron porque el gobernador lo mandó llamar para que fuera a San Francisco, como fue, con el teniente que mandaba a los soldados, y a este tiempo lo aprehendieron pero el declarante no ha andado con ellos.

Pedro GonZÁlez, 23 años || Español de San Francisco Tetecala || 53. Se le aprehendió por haber dicho a los insurgentes dónde estaba un poco de ropa guardada, y esto lo hizo porque le impusieron pena de la vida, pero no los acompañó para cosa alguna, ni le dieron nada por el soplo.

José Ignacio Miralvio, 29 años || Mestizo de San Francisco Tetecala || 54. Que lo aprehendieron en el mismo pueblo, por el tendero don Juan de Lizarriturri por acusarle de que había expresado que se alegraba que entrasen los insurgentes, pero ni ha andado con ellos, ni tampoco lo ha dicho y que cuando los aprehendieron, después lo fueron a sacar de su casa. 
Cuadro 2. Algunos aprehendidos acusados de ser insurgentes en el Valle de Cuernavaca (continuación) NOMBRE y edad del reo || Oficio, “calidad”y origen || Declaración (se destacan en negritas cuestiones de interés para este artículo)

ManUel ArgüELLES, 20 años || Labrador, asturiano || 55. Que lo aprehendieron en San Francisco Tetecala porque anduvo en la guerra de Temixco con los insurgentes dos días y medio, y esto fue porque lo querían prender como europeo, y por súplicas de su mujer, le dijo Rubalcaba que lo perdonaba, y que fuera en su compañía, como lo hizo, y por eso lo nombró segundo tesorero de la plata labrada que traía y 1500 pesos, dándole al declarante 1 diario, por razón de sueldo... entregó los baúles de San Gabriel, porque el médico le pusiese la espada a los pechos, el cual se llamaba don Miguel Altamirano, pues éste no se apartaba del lado del comandante... Careado dicen dos testigos... que qué gana tenía de andar con esas mentiras de que estaba por fuerza en el ejército, cuando él fue el que alborotó el pueblo de San Francisco Tetecala y mandó a los declarantes [de apellido Cortés y Sánchez] que echaren mano a la espada, mandando también repicar para que se juntasen los indios, porque ya los gachupines habían ganado la hacienda de Temixco y ya venían cerca, diciéndoles también a los declarantes Sánchez y Cortés, que les aseguraba 12 fusiles y se arriesgaba a hacer cañones aunque sea de barro que entendía de ello... Pena de horca al que no lo acompañara... Contestando Argüelles que sus dos careados le pusieron los trabucos en sus pechos, y por lo mismo mandó repicar, y que dijo que se podían hacer cañones aun de cobre, porque la había en la hacienda de San Gabriel... se manifestó confeso, con la excepción de que fue de temor de ellos [los insurgentes].

José Antonio TejedA, 23 años || Velero, mestizo de San Francisco Tetecala || 56. Que sólo medio día anduvo con los insurgentes, y sólo recibió 1 peso. Que su cura es gachupín, que lo llamaba el comandante, y no quiso ir, hasta que lo sorprendió. Y sólo el teniente fue el que lo acompañó [al comandante insurgente].

Mariano Ortega, 33 años || Tratante de aguardiente, indio de Tetecala || 57. Lo aprehendieron por haber comprado 18 varas de manta a 1 real y estando en el saqueo, mucha gente que vino de fuera, se halló el declarante una pieza de ralladillo y un frasco de cristal vacío, así lo aprehendieron. Se lo entregó al teniente. No estuvo en el tumulto.

José Ignacio Manzanar, 26 años || Talabartero, indio de Izúcar || 58. Es vecino de Tetecala. Un tal Pepe Cázares le vio cuatro piezas de manta y le levantó testimonio falso, que sólo estuvo después del saqueo.

Proquinto Morales, 34 años || Pintor, mestizo de Taxco || 59. Que en el saqueo que hubo en Tetecala en la tienda de don José Rivera, tomó dos tablas y un cuartón que estaba tirado afuera y por esto lo redujeron a prisión.

José AnTONIO DE Jesús, 20 años \| Operario del campo, indio de Cuautla || 60. Lo aprehendieron en su milpa que está en el camino de San Gabriel, sin que haya cometido delito alguno.

Alejo EnRiQUe, 40 años \|| Yuntero, indio de San Felipe Xoxocotla || 61. Expresó por medio de Florentino Roldán que hizo oficio de intérprete... que habiendo herido a su hijo otro, llamado Guadalupe Francisco, por una riña que tuvieron en el pueblo, y bajado ambos a Cuernavaca, vino el declarante a este lugar en busca de su hijo y dos leguas antes de llegar lo prendieron unos gachupines. Preguntado dónde vio a los insurgentes... dijo que en ninguna parte.

Pedro José Ortega, 35 años || Sastre, español de Jerécuaro || 62. Que habiéndose listado voluntariamente de soldado de a caballo en el ejército de Allende, en la compañía que traía a su cargo un capitán, nombrado don Gregorio, cuyo apellido ignora, lo hizo por interés de percibir 1 peso diario que daban para mantener a su familia por ser muy pobre cargado de ella. En la hacienda de Jalmolonga vio el declarante que extrajeron de ella mucha ropa de la tierra, gamuzas y calzones ya hechos... en la hacienda de Actopan había ropa... Que venido para la hacienda de San Gabriel fueron bien recibidos y los efectos de la tienda, esto es la mitad de ellos, porque decían la tenía en compañía, la tiraron, a que escogieran quien quisiera, y la otra mitad se la dejaron a un don Ramón, porque éste era criollo. Que del mismo San Gabriel lo trajeron preso a esta capital. 
Cuadro 2. Algunos aprehendidos acusados de ser insurgentes en el Valle de Cuernavaca (continuación) NOMBRE y edad del reo \| Oficio, "calidad”y origen || Declaración (se destacan en negritas cuestiones de interés para este artículo)

IgNACIO ESQUivel, 40 años || Labrador, mestizo || 63. Asistente que fue del comandante Rubalcaba. Dijo que le sirvió al dicho comandante desde el 15 de septiembre, que era de un lado de Salamanca, y tiene un ranchito en Acambay. Y que yendo para Guanajuato, dicho Rubalcaba, tuvo noticia de que un hermano suyo venía de médico con el ejército insurgente, y que estaba en Acámbaro, adonde se fue a incorporar. Y le dieron el empleo de comandante y entonces comenzó a reclutar gente en San Miguel Jerécuaro, valiéndose del gobernador nombrado Lázaro Lizalde, que le daría como 150 hombres. Y de ahí pasaron a Acambay, donde se le presentaban muchas gentes, viniéndose para Toluca, donde ya había estado el ejército grande [de Hidalgo]. Que todo el dinero que se había quitado a las haciendas y lugares donde habían estado, que serían como 7000 pesos, la plata labrada y unos baúles, quedaron en la hacienda de San Gabriel. Que como el declarante no conoce los pueblos, no puede decir qué justicias y curas lo recibieron bien, pero todos éstos los recibían bien... que el hermano que viene con el ejército tiene una tienda a un lado de Salamanca en Irapuato. Que al declarante le daban 4 pesos y medio mensuales, sin que le haya tocado más que unos calzones.

Miguel SÁnCHEZ, 17 años || Oficial barbero, español de Jerécuaro || 64. Que viniendo el comandante Rubalcaba de Jerécuaro con porción de gente, estando el declarante inmediato a donde él pasó, dijeron se alistasen, que darían 1 peso al que tuviera silla de montar y 4 reales al que no tuviere, que era para defender la patria y la ley. Por lo que el declarante lo acompañó, dándole plaza de cabo, y pasaron a Acambay, a Atlacomulco, luego a Toluca, a Jalmolonga, Tenancingo, Zompahuacan y después a Actopan y de allí a San Gabriel, que fue donde se quedó el declarante. Que en los más lugares, donde había europeos mandaba robar carne, caballos y demás bienes con dinero. Y daba orden de pena de vida al soldado que robase alguna cosa, cuando llegaba a alguna hacienda o tienda, donde entraba él solo con su bastón y espada, con cuatro lanceros, sacaba el dinero, indianas y demás de valor, y después mandaba que entraran los criollos y sacaran lo que había. Que el deponente no sabe cómo lo mataron... que no le parecía que era malo, respecto a que por los más lugares donde transitó... le replicaban.

José Luis Moreno, 18 años || Tejedor, español de Calimaya || 65. Cinco días acompañó a los insurgentes y sólo le dieron 12 reales.

JUAN José LuZ, “como de” 18 años || Gañán, indio de Zinacantepec || 66. Que sólo dos días estuvo con los insurgentes y sólo le dieron 4 reales.

Polinario HernándeZ, 25años || Mediero || 67. Que anduvo tres días con el ejército y sólo le dieron 1 peso.

AnTonio Díaz, 33 años || Gañán, mestizo de Calimaya \| 68. Que sólo seis días anduvo y le dieron 5 pesos.

Pioquinto Martín, 30 años || Tejedor, indio de Toluca || 69. Estuvo con los insurgentes tres días y le dieron 4 reales.

Laureano José, 30 años || Tejamanilero, indio de San Pedro Tzitepeque || 70. Sólo tres días anduvo con ellos y le dieron 12 reales.

Antonio Tobar, 25 años || Gañán, mulato de Jerécuaro || 71. Tres semanas anduvo con ellos y le dieron 5 pesos porque los engañan.

Esteban Muñoz, 24 años || Carpintero, de Ucareo || 72. Anduvo ocho días con ellos y sólo le dieron 1 peso, reservándole lo demás. Que era asistente de un tal don Gregorio que era capitán. Que no sabe su paradero... ignora de dónde era vecino, pues él eligió al declarante sin tener conocimiento de él. 
Cuadro 2. Algunos aprehendidos acusados de ser insurgentes en el Valle de Cuernavaca (continuación) NOMBRE y edad del reo \| Oficio, "calidad”y origen \| Declaración (se destacan en negritas cuestiones de interés para este artículo) José CRistóbal Velásquez, 30 años || Sastre de Jerécuaro || 73. Sólo cinco días anduvo con el ejército y le dieron 20 reales.

José Francisco GarCía, 20 años \| Vaquero, español del rancho de Lara en Temascalcingo \| 74. Cinco días anduvo con los insurgentes y le dieron 5 pesos, y esto fue porque un padre agustino predicó en el pueblo de Malinalco, en la hacienda de Jalmolonga, que tenía un hábito blanco, diciendo que él había de acompañar el ejército hasta derramar la última gota de su sangre.

Pioquinto Ceballos, 18 años || Tejedor, mestizo de Tenancingo || 75. Cinco días anduvo con el ejército y sólo le dieron 12 reales.

MÁximo Alderete, 24 años $\|$ Sastre, español de Xerez $\|$ 76. Sólo cuatro días [anduvo con el ejército], le dieron 2 reales porque no estaba el comandante.

José Germán Avilez, 25 años || Sillero, español de Tenancingo || 77. Cuatro días [anduvo], no le dieron ni blanca [arma], porque le iba sirviendo al colector de Tenancingo, que lo llevaban preso, y por encargo de la familia de éste, es que está en dicho pueblo. Fue a los fines dichos. Y como en la hacienda de San Gabriel los prendieron a todos de montón, lo hicieron con el declarante, porque lo vieron en el ejército. Que el dicho colector quedó en la hacienda de San Gabriel libre.

José Antonio Martínez, 36 años || Gamucero, indio de Tenancingo || 78. Sólo cinco días [anduvo], le dieron 20 reales.

Francisco de la Cruz, 13 años || Gañán, indio de Tepostepeque || 79. Cuatro días anduvo, ellos le dieron 1 peso. No robó nada.

José ViCente, 16 años \|| Gañán, indio de Tepostepeque || 80. Sólo tres días [anduvo], y le dieron 1 peso.

José Quirino Romero, 28 años || Cardador, mulato de Purúas || 81. Anduvo con el ejército 11 días, con 4 reales diarios, habiéndole tocado dos gamuzas que le dio el comandante y lo que robó, cuatro varas de tripa, una pieza de manta y cuatro y media de cordobanes y una bolsita de café, quedando todo en San Gabriel.

Mariano Bruno, 27 años || Tejedor, indio de Toluca \| 82. Anduvo con los insurgentes tres días, le dieron 12 reales. De los robos le tocaron cinco varas de manta que le dieron y que don Ignacio Torres, Justicia de Tenancingo, andaba con el comandante.

Pascual de los Reyes, "no sabe, como de" 14 o 16 años \|| Arriero, indio de Tetipaque || 83. Bastante ladino en el idioma castellano. Que desde la hacienda de San Gabriel, que está a un lado del camino del puerto de Acapulco, se introdujo con los del ejército de Allende, y anduvo con ellos dos días, hasta que lo prendieron un domingo, cuya fecha no tiene presente, y sí que habrá como 15 días.

Silvero José, "representa ser mayor de" 25 años || Calero, indio de Zumpahuachan || 84. Que el lunes después de la semana de muertos llegaron a su pueblo los insurgentes y al otro día martes salieron. Que el sábado los fue a alcanzar el declarante y esa noche se alistó con ellos, andando juntos hasta el domingo siguiente, como a las tres de la tarde, que los prendieron. 
Cuadro 2. Algunos aprehendidos acusados de ser insurgentes en el Valle de Cuernavaca (continuación) NOMBRE y edad del reo \| Oficio, "calidad"y origen \| Declaración (se destacan en negritas cuestiones de interés para este artículo)

PEDRO SÁnCHEZ || Tendero y fabricante de aguardiente, español de Xochitepec || 85. Que el lunes 12 de noviembre llegaron los insurgentes a Xochitepec con muchos indios forasteros que no conocía y el que mandaba tenía "un bastoncito al lado izquierdo del chaquetón y en una mano una espada y era el que mandaba”. Con su llegada se alborotó el pueblo y junto con Pascual de los Reyes mandaron hacer unas lanzas al herrero.

PASCUALDE LOS ReYeS, 40 años \| Gobernador, indio de Xochitepec $\|$ 86. Que recibió aviso el lunes 5 del corriente [noviembre]... que aunque lo llamaran al Juzgado [de Cuernavaca] no viniera, aunque lo pusieran en la cárcel y que había de obedecer al señor Allende... y el viernes le dieron un papel diciéndole que era cordillera para citar a los pueblos y que inmediatamente lo llevase a Atlacholoaya... que cerró la tienda para tenerla a disposición de Allende... que habiendo llenado un chiquihuite de fierro de la tienda lo dio el comandante y dijo que aquello era para hacer lanzas.

MATíAs, 68 años || Labrador, indio de Huajintlan || 87. Lo aprehendieron porque el gobernador [de su pueblo de Huajintlan] no acudió al llamado que le hizo el teniente de Tetecala, por tercer oficio, de modo que cuando llegó la tropa del rey echó al río a la gente del pueblo, las mujeres con las criaturas, de modo que se ahogó mucha gente y además quemaron el pueblo, llevándose las tropas todo el ganado para la hacienda de San Gabriel.

Rosalino José, 35 años || Gobernador, indio de Jiutepec \| 88. Que a pocos días de haberse ido para México el señor alcalde mayor [subdelegado] don Manuel de Fuica [enero 1812], estando esta jurisdicción inundada de insurgentes se vio el declarante obligado a salirse de su pueblo... marchó con los señores a Cuautla, regresó después y lo encarcelaron los insurgentes en Cuernavaca... el padre vicario de Jiutepec le habló con entusiasmo que los gachupines ya no volverán a sus casas... que habían abierto los puertos a los franceses que venían en defensa de los americanos.

José RAmÓn CORTÉS, 19 años || Sin oficio, español de Valladollid, vecino de Zinapécuaro || 89. Se introdujo desde el pasado 27 de octubre [de 1810] en el ejército del comandante Rubalcaba, por instancia de éste... que lo ocupaba de escribiente por lo que le daba 1 peso diario y el día 11 o 12 lo prendieron en Tetecala, al tiempo que se iba de retirada a su tierra... que sólo una carta le escribió para el cura Hidalgo, dándole razón de los reales que había sacado de los estancos, y lo que había ejecutado por donde había caminado. Cuya carta le dirigió a la ciudad de México, porque pensaba ya estaban en ella, y lo demás que escribió eran los recibos que entregaba en los mismos estancos, resguardos que daba y demás que se le ofrecía a la mano.

JUAN ANDRÉS, 40 años || Labrador, indio de Jiutepec || 90. Que retirado el gobernador de su pueblo [enero de 1812]... se quedó el pueblo sin más gobierno que los pocos oficiales de república que tiene, y entonces los viejos y demás hijos de él, nombraron al declarante de gobernador... cuyo empleo aceptó y después avisaron al vicario de su pueblo Bachiller don Pedro Gómez... que a pocos días un coronel insurgente que le decían Sánchez, le dio al declarante mandamiento... saliese con sus avanzados... a avisar si venían gachupines, para que diesen aviso a esta villa de Cuernavaca. Que por no tener armas, mandó el padre Herrero, que estaba en esta villa, que ya no saliesen.

Fuentes: AGN Criminal, vol. 48, e. 11, f. 198-212. AGN, Criminal, v. 204, f.235-238, 282v. Declaraciones 85, 86 y 87. AGN, Criminal, v. 44, exp. 11, f. 287-302.

"Averiguación y causa que se hizo en junio de 1812 al cura de Jiutepec", núms. 88 y 90. 


\section{Bibliografía}

Alamán, Lucas, 1972, Historia de Méjico, 5 vols., Jus, México. Brading, D. A., 1975, Mineros y comerciantes en el México borbónico (1763-1810), Fondo de Cultura Económica, México.

Bustamante, Carlos María de, 1988, Campañas del general D. Feliz María Calleja, comandante en jefe del ejército real de operaciones llamado del centro, Fundación Miguel Alemán, México.

Castro Gutiérrez, Felipe, 1996, Nueva ley y nuevo rey. Reformas borbónicas y rebelión popular en Nueva España, El Colegio de Michoacán, Universidad Nacional Autónoma de México, México.

Chávez Orozco, Luis, 1976, El sitio de Cuautla, Partido Revolucionario Institucional, Comité Ejecutivo Nacional, México.

De la Torre Villar, Ernesto, 1966, Los Guadalupes y la Independencia de México: con una selección de documentos inéditos, Jus, México.

Guedea, Virginia (selec. e introd.), 1995a, La Revolución de Independencia, Lecturas de Historia Mexicana, núm. 10, El Colegio de México, México.

_ (introd. y notas), 1995b, Prontuario de los insurgentes, Instituto Mora, Centro de Estudios sobre la Universidad, Universidad Nacional Autónoma de México, México.

Hamnett, Brian, 1990, Raíces de la insurgencia en México. Historia regional, 1750-1824, Fondo de Cultura Económica, México.

Hernández Jaimes, Jesús, 2002, Las raíces de la insurgencia en el sur de la Nueva España. La estructura socioeconómica del centro y costas del actual estado de Guerrero durante el siglo XVIII, H. Congreso del Estado de Guerrero, Instituto de Estudios Parlamentarios Eduardo Neri, México.

Humboldt, Alejandro de, 1966, Ensayo politico sobre el reino de la Nueva España, Porrúa, México.

Lemoine, Ernesto, 1990, Morelos y la Revolución de 1810, Universidad Nacional Autónoma de México, México.

López, Valentín, 1994, Cuernavaca, visión retrospectiva de una ciudad, Ayuntamiento de Cuernavaca, Centro de Estudios Históricos y Sociales del Estado de Morelos, México.

Martin, Cheryl, 1985, Rural Society in Colonial Morelos, University of New Mexico Press, Albuquerque.
Mentz, Brígida von, 1988, Pueblos de indios, mulatos y mestizos, Centro de Investigaciones y Estudios Superiores en Antropología Social, México.

—_ et al., 1989, Sultepec en el siglo XIX, El Colegio Mexiquense, Universidad Iberoamericana, México.

__, 1997, "Coyuntura minera y protesta campesina en el centro de la Nueva España, siglo XVIII", en Inés Herrera Canales (coord.), La minería mexicana. De la Colonia al siglo XX, Instituto Mora, El Colegio de Michoacán, El Colegio de México, Instituto de Investigaciones Históricas, Universidad Nacional Autónoma de México, México, pp. 23-45.

— y R. Marcela Pérez López (comps.), 1998, Manantiales, ríos, pueblos y haciendas. Dos documentos sobre conflictos por aguas en Oaxtepec y en el Valle de Cuernavaca (1795-1807), Instituto Mexicano de Tecnología del Agua, Centro de Investigaciones y Estudios Superiores en Antropología Social, México.

— 1999, Trabajo, sujeción y libertad, Centro de Investigaciones y Estudios Superiores en Antropología Social, Porrúa, México.

—_ (coord.), 2003, Movilidad social de sectores medios en México. Una retrospectiva histórica (siglos XVII al XX), Centro de Investigaciones y Estudios Superiores en Antropología Social, Porrúa, México.

_- (en prensa), "La insurrección llega a los valles de Cuernavaca (1810-1812)”, en Ernest Sánchez Santiró (coord.) y Horacio Crespo (dir.), Historia de Morelos. Tierra, gente, tiempos del sur, , tomo V, H. Congreso del Estado de Morelos, México.

Miquel i Vergés, José María, 1969, Diccionario de Insurgentes, Porrúa, México.

Ortiz Escamilla, Juan, 1997, Guerra y gobierno. Los pueblos y la independencia de México, Instituto Mora, El Colegio de México, Universidad de Sevilla, Universidad Internacional de Andalucía, Sevilla.

Sánchez Santiró, Ernest, 2001, Azúcar y poder. Estructura socioeconómica de las alcaldías mayores de Cuernavaca y Cuautla de Amilpas, 1730-1821, Praxis, Universidad Autónoma de Morelos, México.

Van Young, Eric, 2006, La otra rebelión. La lucha por la independencia de México, 1810-1821, Fondo de Cultura Económica, México. 